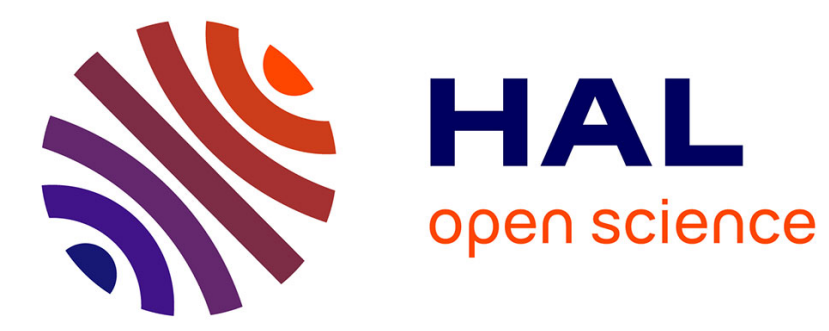

\title{
Mont Terri rock laboratory, 20 years of research: introduction, site characteristics and overview of experiments
}

\author{
P. Bossart, F. Bernier, J. Birkholzer, C. Bruggeman, P. Connolly, S. Dewonck, \\ M. Fukaya, M. Herfort, M. Jensen, J.-M. Matray, et al.
}

\section{To cite this version:}

P. Bossart, F. Bernier, J. Birkholzer, C. Bruggeman, P. Connolly, et al.. Mont Terri rock laboratory, 20 years of research: introduction, site characteristics and overview of experiments. Swiss Journal of Geosciences, 2017, 110 (1), pp.3-22. 10.1007/s00015-016-0236-1 . hal-02551286

\section{HAL Id: hal-02551286 \\ https://hal.science/hal-02551286}

Submitted on 7 Jul 2020

HAL is a multi-disciplinary open access archive for the deposit and dissemination of scientific research documents, whether they are published or not. The documents may come from teaching and research institutions in France or abroad, or from public or private research centers.
L'archive ouverte pluridisciplinaire HAL, est destinée au dépôt et à la diffusion de documents scientifiques de niveau recherche, publiés ou non, émanant des établissements d'enseignement et de recherche français ou étrangers, des laboratoires publics ou privés. 


\title{
Mont Terri rock laboratory, 20 years of research: introduction, site characteristics and overview of experiments
}

\author{
Paul Bossart ${ }^{1}\left[\right.$ Frédéric Bernier $^{2} \cdot$ Jens Birkholzer $^{3} \cdot$ Christophe Bruggeman $^{4}$. \\ Peter Connolly $^{5}$ - Sarah Dewonck $^{6} \cdot$ Masaaki Fukaya $^{7} \cdot$ Martin Herfort $^{8}$. \\ Mark Jensen $^{9} \cdot$ Jean-Michel Matray ${ }^{10}$ - Juan Carlos Mayor ${ }^{11} \cdot$ Andreas Moeri $^{1}$. \\ Takahiro Oyama $^{12} \cdot$ Kristof Schuster $^{13} \cdot$ Naokata Shigeta $^{14} \cdot$ Tim Vietor $^{15}$. $^{1}$ \\ Klaus Wieczorek ${ }^{16}$
}

Received: 28 April 2016/Accepted: 9 December 2016/Published online: 21 February 2017

(C) The Author(s) 2017. This article is published with open access at Springerlink.com

\begin{abstract}
Geologic repositories for radioactive waste are designed as multi-barrier disposal systems that perform a number of functions including the long-term isolation and containment of waste from the human environment, and the attenuation of radionuclides released to the subsurface. The rock laboratory at Mont Terri (canton Jura, Switzerland) in the Opalinus Clay plays an important role in the development of such repositories. The experimental results gained in the last 20 years are used to study the possible evolution of a repository and investigate processes closely related to
\end{abstract}

Editorial handling: A. G. Milnes.

This is the introductory paper (including a list of abbreviations and acronyms) to accompany the 20 research papers (papers 1-20) included in the Special Issue.

Electronic supplementary material The online version of this article (doi:10.1007/s00015-016-0236-1) contains supplementary material, which is available to authorized users.

Paul Bossart

paul.bossart@swisstopo.ch

1 Federal Office of Topography swisstopo, Seftigenstrasse 264, 3084 Wabern, Switzerland

2 Federal Agency for Nuclear Control FANC, Rue Ravenstein 36, 1000 Brussels, Belgium

3 Lawrence Berkeley National Laboratory, Berkeley, CA 94720 , USA

4 Belgian Nuclear Research Centre SCK.CEN, Boeretang 200, $2400 \mathrm{Mol}$, Belgium

5 CHEVRON, Rock Mechanics Team, Chevron ETC, 1500 Louisiana Street, Houston, TX 77002, USA

6 Agence Nationale pour la Gestion des Déchets Radioactifs ANDRA, Centre de Meuse Haute-Marne, RD 960, 55290 Bure, France the safety functions of a repository hosted in a clay rock. At the same time, these experiments have increased our general knowledge of the complex behaviour of argillaceous formations in response to coupled hydrological, mechanical, thermal, chemical, and biological processes. After presenting the geological setting in and around the Mont Terri rock laboratory and an overview of the mineralogy and key properties of the Opalinus Clay, we give a brief overview of the key experiments that are described in more detail in the following research papers to this Special Issue of the Swiss Journal of Geosciences. These experiments aim to characterise the Opalinus Clay and estimate safetyrelevant parameters, test procedures, and technologies for repository construction and waste emplacement. Other aspects covered are: bentonite buffer emplacement, high$\mathrm{pH}$ concrete-clay interaction experiments, anaerobic steel corrosion with hydrogen formation, depletion of hydrogen by microbial activity, and finally, release of radionuclides

7 Nuclear Facilities Division, Nuclear Waste Technology Department, OBAYASHI Corporation, 2-15-2, Konan, Minato-ku, Tokyo 108-8502, Japan

8 Swiss Federal Nuclear Safety Inspectorate ENSI, Industriestrasse 19, 5200 Brugg, Switzerland

9 Nuclear Waste Management Organization (NWMO), 22 St. Clair Ave. E., Toronto, ON, Canada

10 Institut de Radioprotection et de Sûreté Nucléaire, 31, Avenue de la Division Leclerc, 92260 Fontenay-aux-Roses, France

11 Empresa Nacional de Residuos Radiactivos S.A.ENRESA, Calle de Emilio Vargas, 7, 28043 Madrid, Spain

12 Geosphere Environmental Science Department, Abiko Research Laboratory, Central Research Institute of Electric Power Industry CRIEPI, 1646, Abiko, Chiba 270-1194, Japan 
into the bentonite buffer and the Opalinus Clay barrier. In the case of a spent fuel/high-level waste repository, the time considered in performance assessment for repository evolution is generally 1 million years, starting with a transient phase over the first 10,000 years and followed by an equilibrium phase. Experiments dealing with initial conditions, construction, and waste emplacement do not require the extrapolation of their results over such long timescales. However, experiments like radionuclide transport in the clay barrier have to rely on understanding longterm mechanistic processes together with estimating safety-relevant parameters. The research at Mont Terri carried out in the last 20 years provides valuable information on repository evolution and strong arguments for a sound safety case for a repository in argillaceous formations.

Keywords Underground research laboratory (URL) . International research programme $\cdot$ Nuclear waste disposal - Repository evolution · In situ experiments . THMC processes $\cdot$ Switzerland

\section{Introduction}

\subsection{Objectives of underground rock laboratories}

An underground rock laboratory (URL) is a research facility in which site characterisation and testing activities are carried out, along with technology development and demonstration activities in support of the development of deep geological repositories for disposal of radioactive waste (OECD 2013). Therefore, the prime objectives of investigation programs in rock laboratories are to acquire data that will provide in-depth understanding of long-term performance of repository components in a geological environment, and to obtain data that will be used as a starting-point for development and testing of safety assessment models. A further objective is to demonstrate and optimise key components of the engineered barrier system (e.g. testing of canister and backfilling materials and its interaction with the host rock). An important

13 Federal Institute for Geosciences and Natural Resources BGR, Stilleweg 2, 30655 Hannover, Germany

14 Japan Atomic Energy Agency JAEA, 432-2 Hokushin, Horonobe-cho, Hokkaido 098-3224, Japan

15 National Cooperative for the Disposal of Radioactive Waste NAGRA, Hardstrasse 73, 5430 Wettingen, Switzerland

16 Gesellschaft für Anlagen- und Reaktorsicherheit (GRS) GmbH, Process Analysis Department, Final Repository Safety Research Division, Theodor-Heuss-Strasse 4, D-38122 Braunschweig, Germany contribution of a rock laboratory is to investigate the selected geological environment and to test models at more appropriate scales and conditions than can be achieved at the surface. A final objective is the evaluation of transferability of individual parameters, investigation techniques, data evaluation methods, process understanding, and conceptual models to reach high-level conclusions (e.g. engineering feasibility, safety aspects) relevant to a safety case ${ }^{1}$ for a future repository program (Mazurek et al. 2008; Blechschmidt and Vomvoris 2010; Delay et al. 2014; Alexander et al. 2015).

There are two types of URL: generic and site-specific. Generic URLs are independent of final disposal sites and comprise facilities that are developed for research and testing purposes at a site that will not be used for waste disposal. Site-specific URLs are located in the host rock in an area that is considered as a potential future repository. They include facilities that are developed for specific investigations at the given site and may, indeed, be a forerunner to the development of a repository at that site. During the last 40 years, about 30 generic and site-specific URLs have been constructed and about half of them are still in operation (Blechschmidt and Vomvoris 2010). Many of these URLs were constructed in granitic (40\%) but the majority $(60 \%)$ in sedimentary rocks, such as bedded salt and salt domes, clays, tuffs, limestones, and diatomite. There are three major URLs in claystones: (1) the site-specific Meuse/Haute Marne URL, located in the Paris basin in France at a depth of $490 \mathrm{~m}$ in the stiff Callovian-Oxfordian clay formation, and operated by ANDRA; (2) the site-specific Hades URL at a depth of $225 \mathrm{~m}$ in the plastic Boom Clay in Belgium at a depth of $225 \mathrm{~m}$, operated by SCK.CEN; and (3) the generic Mont Terri rock laboratory, located in the canton Jura in Switzerland at a depth of $280 \mathrm{~m}$ in the stiff Opalinus Clay, operated by the Swiss Geological Survey at swisstopo (Swiss Federal Office of Topography). This Special Issue of the Swiss Journal of Geosciences presents 20 papers describing the key experiments that have been carried out during the last 20 years of applied research at the generic Mont Terri rock laboratory. In this introductory paper, we give an overview of the papers comprising this Special Issue and placing them within a conceptual scheme of repository evolution.

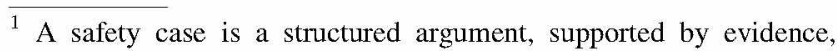
intended to justify that a system is acceptably safe. According to the IAEA (2012), it is "...the collection of scientific, technical, administrative and managerial arguments and evidence in support of the safety of a disposal facility, covering the suitability of the site and the design, construction and operation of the facility, the assessment of radiation risks and assurance of the adequacy and quality of all of the safety related work associated with the disposal facility".
} 


\subsection{Research in the Mont Terri rock laboratory}

The Mont Terri rock laboratory lies north of the town of StUrsanne in the canton of Jura. The research facilities are located at a depth of $280 \mathrm{~m}$ below the surface and are accessed through the security gallery of the Mont Terri tunnel of the A16-Transjura highway, which passes through the Jura mountain range. The research galleries in the Opalinus Clay layer have a total length of ca. $700 \mathrm{~m}$.

The major aims of the international Mont Terri research project are to investigate and analyse the hydrogeological, geochemical, and rock mechanical properties of argillaceous formations. The Mont Terri rock laboratory offers a scientific and technical platform for international collaboration in the field of deep geological disposal. In the Mont Terri rock laboratory, experiments are dedicated to investigate the properties of a pristine claystone, the Opalinus Clay, its perturbation when an underground opening is constructed, the early and late time interplay of engineered barriers and the natural claystone barrier, and ultimately the understanding of the migration of radionuclides at varied length (near and far-field) and timescales. The latter experiments lead to an increase in confidence in estimating radionuclide mass transport through engineered and natural barriers and improving the reliability of the predictive numerical tools. Understanding mass transport processes is central to a repository safety case.

The Swiss Geological Survey at swisstopo is responsible for operation of the facility and directs the international Mont Terri project. Sixteen organisations from Belgium, Canada, France, Germany, Japan, Spain, Switzerland, and the USA, all of which are considering clay formations as potential host rocks for deep geological disposal of radioactive waste, are involved in the underground (in situ) experiments.

The Opalinus Clay has been selected in Switzerland as the preferred host rock for disposal of high-level waste (HLW) and is among the possible host rocks for low- and intermediate-level radioactive waste (LLW, ILW). A sectoral plan process, led by the Swiss Federal Office of Energy (SFOE), is now underway with the objective of selecting sites for deep geological repositories (SFOE 2008). However, the Mont Terri rock laboratory is first and foremost a research facility for international implementers and safety organisations to conduct collaborative international science and research projects in a low-permeability, smectite-rich claystone with self-sealing (swelling) properties. In this sense, the Mont Terri rock laboratory can be considered as a generic underground rock laboratory. Disposal of radioactive waste will not be considered here. However, some of the experiments at the Mont Terri rock lab should be seen in the context of a potential repository in Opalinus Clay at other locations in northern Switzerland
(Nagra 2002, 2010). These include experiments dealing with the horizontal emplacement of waste canisters and demonstration of selected aspects of the Swiss multi-barrier concept.

This introductory paper gives an overview of the geology in and around the Mont Terri rock laboratory (Sect. 2). In Sect. 3, we outline all the experiments that have been carried out over the last 20 years, and give an overview of the papers in this Special Issue and correlate them with the evolution of a potential repository in the Opalinus Clay. In Appendix, we list abbreviations and acronyms which are used throughout the Special Issue with their explanations. For a glossary of technical terms, we refer to Alexander et al. (2015), and to the IAEA-website: http://www-pub. iaea.org/books/IAEABooks/6682/Radioactive-Waste-Man agement-Glossary.

In the Electronic Supplementary Material attached as Online Resources 1-9 to the present paper, we give additional information about the Mont Terri research project for consultation online (Online Resource 1: explanatory text. Online Resources 2-9: figures and tables). There, we present the partner organisations that are involved in the research project together with their key persons, a retrospective historical overview over the last 30 years, the financial investments, and the project organisation between research partners, operator and owner of the facility. Furthermore, we present a complete list of performed and ongoing experiments since 1996, together with a map of the rock laboratory showing where these experiments are localised.

\section{Site characteristics}

The canton of Jura, where the Mont Terri rock laboratory is located, lies within the Jura mountain belt (Fig. 1). Stratigraphically, this mountain belt encompasses the period from Late Palaeozoic to Quaternary, but the majority of the rocks belong to the "Jurassic" time period. Tectonically, it can be divided into the Folded Jura, an arcuate fold-andthrust belt located to the northwest of the Alpine arc and its foreland basin, extending from Lake Annecy in eastern France to the Zurich area in northern Switzerland and further into southern Germany, and the more external Tabular Jura with undeformed Mesozoic sediments (Fig. 1). The fold-and-thrust belt of the Folded Jura is surrounded by Tertiary basins of different types, to the north the Rhine Graben, to the west the Bresse Graben, and to the southeast the Swiss Molasse Basin. The Rhine and Bresse Grabens are associated with the Oligocene WestEuropean rift system, whereas the Molasse Basin corresponds to an Oligo-Miocene foreland basin, which developed in front of the Alpine orogeny (Sommaruga 1999). 


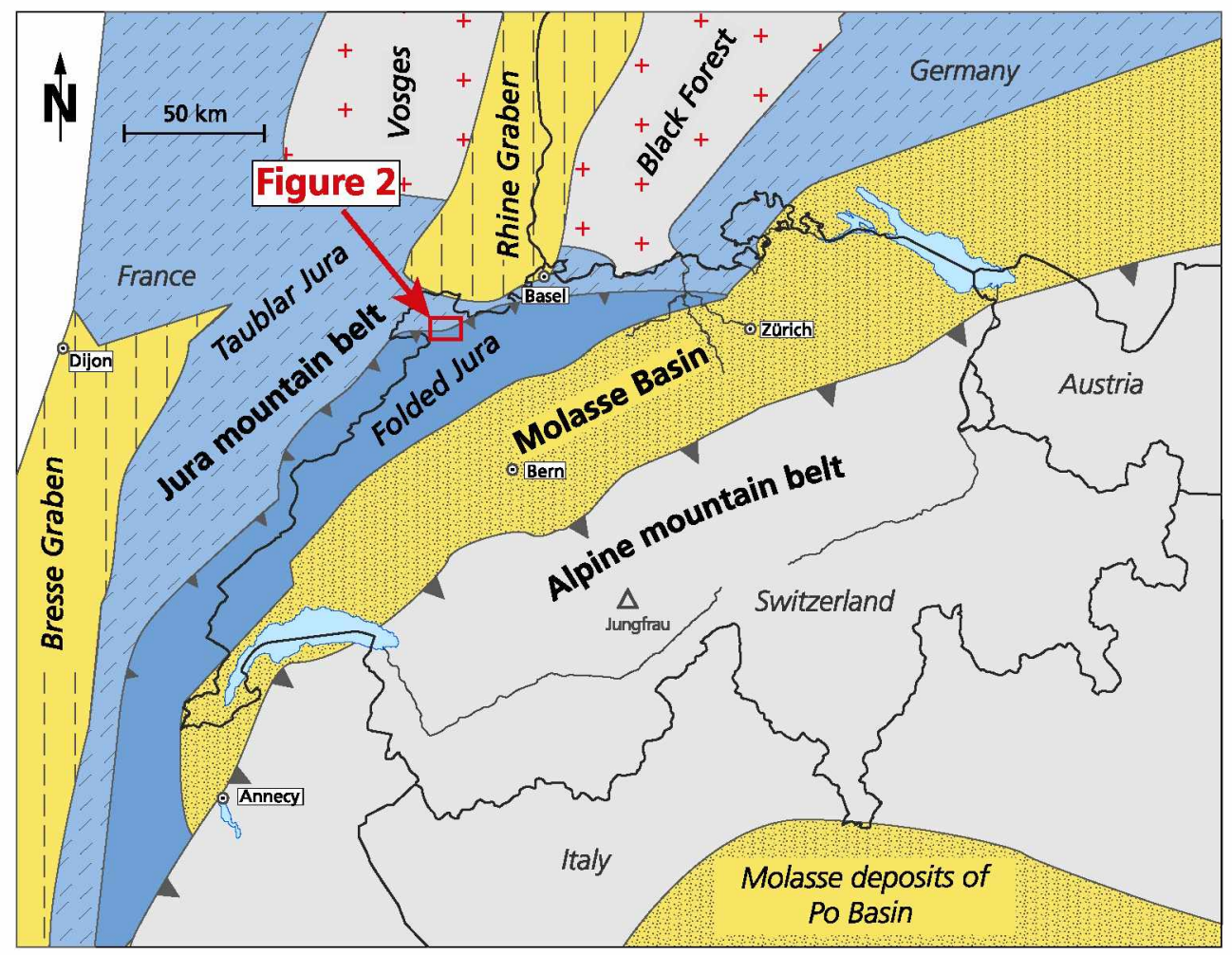

Fig. 1 Sketch map of tectonic units in Switzerland and neighbouring States. The Mont Terri rock laboratory is located in the Canton of Jura besides the Mont Terri motorway tunnel along the A16 Transjurane, in the Folded Jura. The inset refers to the geologic map of Fig. 2

The region of St-Ursanne, where the Mont Terri rock laboratory is located, lies within the Folded Jura, and comprises sedimentary rocks ranging in age from Carboniferous to Quaternary (Fig. 2). The Late Palaeozoic clastic sediments are unconformable overlain by almost $1600 \mathrm{~m}$ of Mesozoic limestones, marls and shales, around $400 \mathrm{~m}$ of Tertiary Molasse, and, locally, Quaternary fluvioglacial sediments. Of special interest are the LiassicDogger units, which comprise several shallowing-upward regressive cycles, starting with the Opalinus Clay and ending with shallow-water carbonates (Blaesi 1987). The Opalinus Clay ${ }^{2}$ consists of a monotonous sequence of dark grey, silty, micaceous clays and sandy shales, deposited around $174 \mathrm{Ma}$ ago. This age is based on a new stratigraphic investigation in a deep borehole cutting the Opalinus Clay and adjacent formations near the rock laboratory

\footnotetext{
${ }^{2}$ Definition and usage of the term "Opalinus Clay": it is regarded in this and following papers as a lithostratigraphic formation, the latter defined as a rock of similar mineralogical and petrophysical properties, which is clearly discernible and mappable as a distinct rock unit in the field. Unweathered, fresh Opalinus Clay is a monotonous succession of dark grey, mica bearing clay and silty marl, with carbonate and sandy lenses that become more abundant towards the top (http://www.strati.ch). According to Wetzel and Alia (2003) the thickness of this formation varies between 60 and $150 \mathrm{~m}$. Its age is of late Toarcian to early Aalenian ( $\sim 174 \mathrm{Ma})$. An update of its litho- and biostratigraphy is given in Hostettler et al. (2017).
}

Fig. 2 Geologic map of the folded and tabular Jura in the region of St-Ursanne, Canton of Jura. The A16 tunnels of Mont Russelin and Mont Terri are projected onto the map and provide the profile trace for Fig. 3. The Mont Terri rock laboratory is located in the southern limb of the Mont Terri anticline. In this large anticlinal fold, two deep boreholes (numbers 1-2) and 3 important surface outcrops (numbers $3-5)$ are indicated. Surface outcrops of Opalinus Clay are rare and altered due to weathering. The traces of the axial planes of the Mont Terri, Caquerelle, and Clairemont anticlines and the sinistral strikeslip faults are shown as the key tectonic structures of this map. The Paleogene and Neogene deposits comprise the following formations: Porrentury conglomerates, Terres jaunes, Meeresand, Septarienton, Alsace Molasse, Upper Marine Molasse (red marls and gompholites), and Upper Freshwater Molasse (Formation du Bois de Raube, Vogesenschotter). Further details are given in the legend. This map is based on the Geological Atlas of Switzerland 1:25,000, map No. 40 "St-Ursanne," (Laubscher 1963), available through swisstopo online under https://map.geo.admin.ch

(Hostettler et al. 2017). The Opalinus Clay is overlain by the Passwang Formation of sandy limestones, shales and oolitic ironstones, and underlain by the Staffelegg Formation consisting of limestones, marls, and shaly intercalations (see geologic map of Fig. 2 and vertical profile of Fig. 3). At Mont Terri and adjacent areas, the Opalinus Clay is barely exposed at the surface. One of the first lithological descriptions of the Opalinus Clay was given by Schmidt et al. (1924) from a borehole near Buix, located about $20 \mathrm{~km}$ to the NW of Mont Terri, where a total 

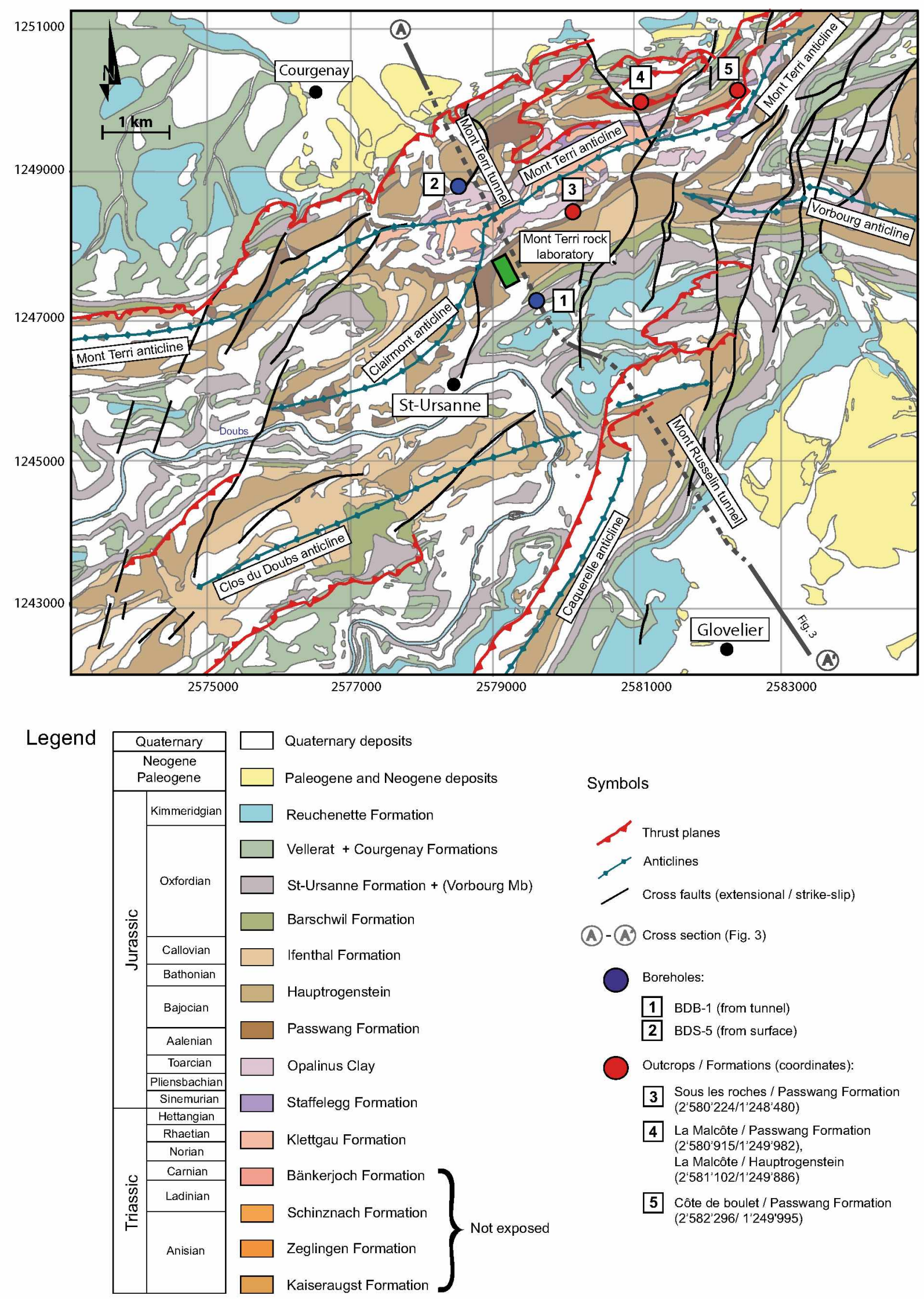

Symbols

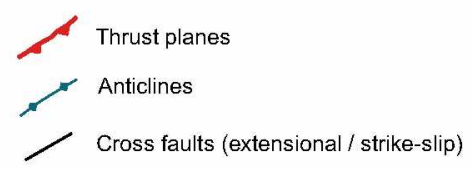

(A) - (A) Cross section (Fig. 3)

Boreholes:

1 BDB-1 (from tunnel)

2 BDS-5 (from surface)

Outcrops / Formations (coordinates):

3 Sous les roches / Passwang Formation (2'580'224/1'248'480)

4 La Malcôte / Passwang Formation (2'580'915/1'249'982), La Malcôte / Hauptrogenstein (2'581'102/1'249'886)

5 Côte de boulet / Passwang Formation (2'582'296/ 1'249'995) 
thickness of $157.5 \mathrm{~m}$ was encountered. The present thickness of the Opalinus Clay in the Mont Terri rock laboratory has been estimated to be $131 \mathrm{~m}$. This corresponds to a sedimentary thickness of about $120 \mathrm{~m}$ when corrected for tectonic overthrusting (Hostettler et al. 2017). The Opalinus Clay at Mont Terri is an overconsolidated claystone. The maximum burial is estimated to have been $1350 \mathrm{~m}$. This results in an overconsolidation ratio of almost 5, assuming a present-day mean overburden of $280 \mathrm{~m}$.

\subsection{Regional tectonic setting}

Nussbaum et al. (2011) describe the regional geologictectonic setting in detail, which we summarise here. Preexisting fault systems together with Permo-Carboniferous grabens and the Rhine-Bresse transfer zone (where the region of St-Ursanne is located) have largely influenced the thrust-and-fold-belt geometry of the Jura Mountains, resulting in complex interference structures such as crossfolds and strike-slip fault zones. Cross-folds occur with different trends, for example, the Caquerelle and Mont Terri anticlines and the divergence of the Mont Terri anticline at its western margin (Figs. 1,2). During the Jura thrusting phase, inherited transcurrent faults from the European Cenozoic intra-continental rifting phase triggered development of both frontal and oblique ramps, depending on fault orientation with respect to transport direction. Consequently, the Mont Terri anticline can be considered as a non-cylindrical domal anticline. Its northeastern border is cut by inherited sinistral strike-slip faults, and its southwestern end is interpreted as the result of cross folding. The detailed kinematic evolution of this structure is described in Nussbaum et al. (2017).

\subsection{Local geology of the Mont Terri rock laboratory}

\subsubsection{Lithofacies}

During construction of the Mont Terri tunnel system in the late 1980s, the reconnaissance gallery of the Mont Terri highway tunnel revealed fresh and high-quality exposures of Opalinus Clay. This led to more detailed lithostratigraphic, hydrogeological, and geochemical descriptions of this formation (Schaeren and Norbert 1989; Tripet et al. 1990; Blaesi et al. 1991, 1996; Gautschi et al. 1993; Hostettler et al. 2017). Not only the discovery of the Opalinus Clay at this locality, but also the simple geometry (limited thrust zones and imbricates) and the possibility of horizontal access, led to establishing the Mont Terri rock laboratory. The laboratory is located entirely in the Opalinus Clay, which can be subdivided into five units and comprises three lithofacies types (Fig. 4). At the bottom there is a shaly facies consisting of mica-bearing marly shales with nodular zones or mm-thick layers of quartz in the silt fraction. Above this there is a sharp transition to a thin carbonate-rich sandy facies, which is characterised by quartz-bearing calcareous biodetritic layers up to $10 \mathrm{~cm}$ thick. Then a sandy facies follows with calcareous silty claystones, and above this a dark-grey, mica-bearing, and slightly silty claystone, which is attributed to the shaly facies. The uppermost unit of the Opalinus Clay consists again of sandy facies, a light-grey silty claystone with lenses of laminated silt and lenses of bioclastic material. Schaeren and Norbert (1989) and Blaesi et al. (1991) defined the base of the Opalinus Clay as a lithological transition of argillaceous sediments to more marly sediments. The latter have been identified as the Gross Wolf

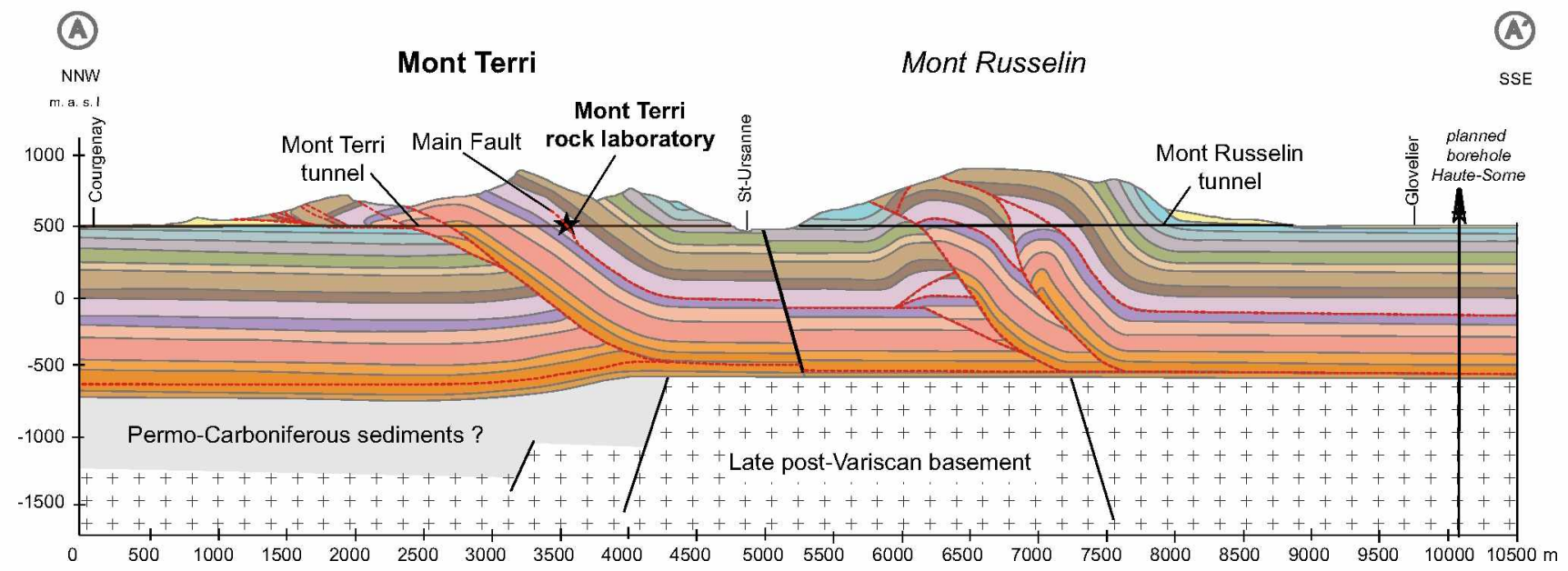

Fig. 3 Balanced geological profile along the Mont Russelin and Mont Terri tunnels. The profile trace is indicated in Fig. 2. These profiles are based on Schaeren and Norbert (1989), Freivogel and Huggenberger (2003), Caër et al. (2015), and Nussbaum et al. (2017).
The latter reference gives the kinematic evolution of this crosssection. Note the simple geometry of the Opalinus Clay in the Mont Terri rock laboratory compared to the Opalinus Clay of the other tunnel outcrops (i.e. Mont Russelin) 


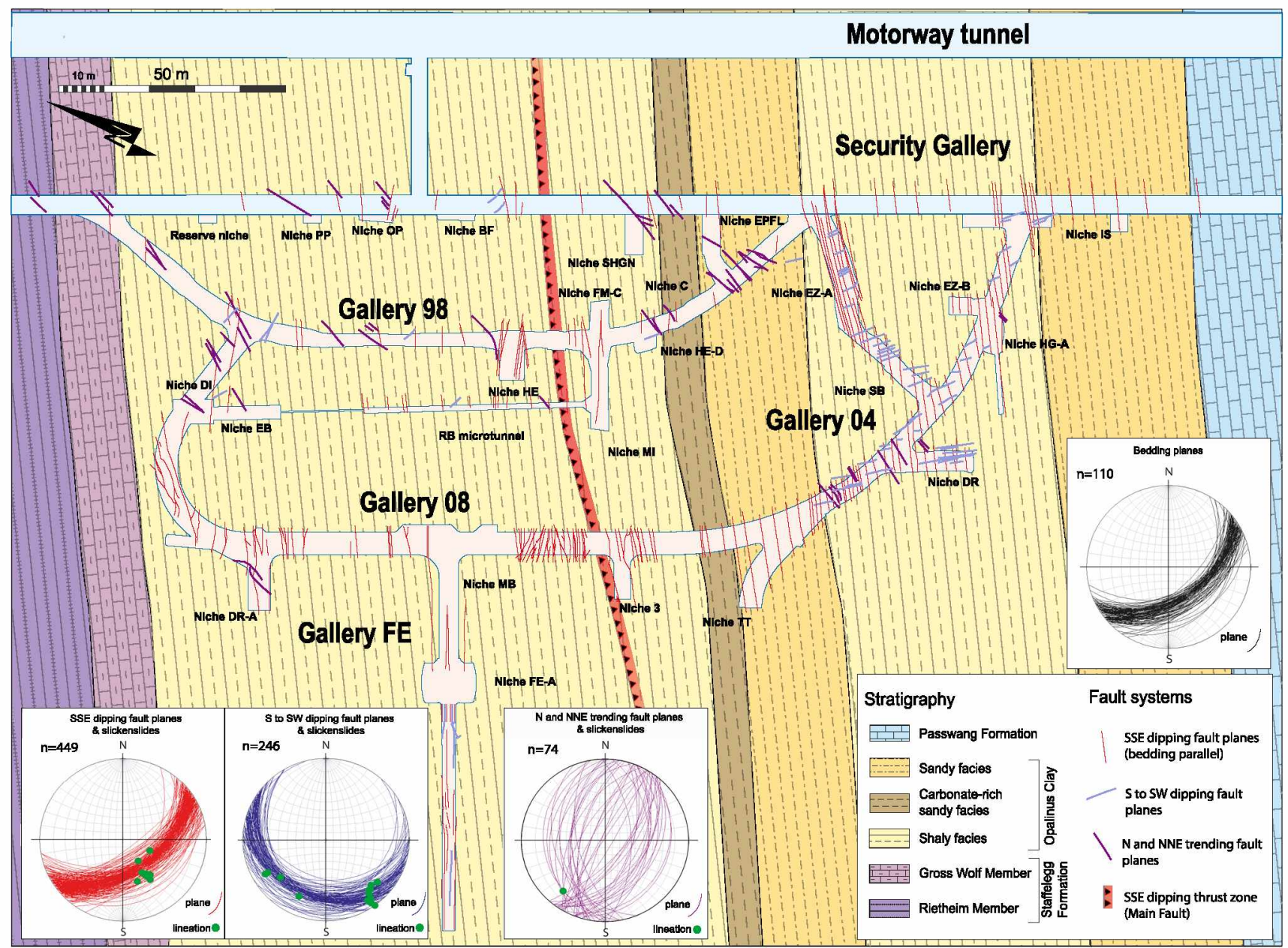

Fig. 4 Geologic-tectonic map of the Mont Terri rock laboratory. The Opalinus Clay is sandwiched between the Staffelegg Formation (base) and the Passwang Formation (top). There are three different facies of Opalinus Clay: shaly, carbonate-rich sandy, and sandy facies. The mapped tectonic faults can be assigned to one of three fault systems as shown on the stereoplots (bottom left, lower hemisphere Wulff projections). The rock laboratory is intersected by a major fault, called the "Main Fault"

developed between 10 and $2 \mathrm{Ma}$ ago at the junction of the frontal part of the Jura thrust-and-fold belt and the RhineBresse transfer zone. The geometry is an imbricate faultbend fold with a component of trishear (Nussbaum et al. 2017). In the Mont Terri rock laboratory, three different fault systems are identified that correlate with regionalscale tectonic structures. The three fault systems are shown in the stereoplots of Fig. 4. They comprise (1) N to NNEstriking steeply inclined normal faults of the Rhine-Bresse graben system reactivated in sinistral strike-slip mode during the Late Miocene Jura thrusting phase, (2) SSEdipping faults subparallel to bedding initiated during the late stage of reverse faulting and anticline folding by flexural slip, and (3) SW-dipping, sub-horizontal faults resulting from lateral extension during thrusting of the Mont Terri anticline above the frontal ramp. The largest tectonic feature in the rock laboratory is the so-called Main 
Fault, a thrust fault zone, which at the rock lab level dips on average about $15^{\circ}$ steeper than bedding planes and exhibits a similar strike direction (Figs. 2, 3).

\subsection{Mineralogy of Opalinus Clay}

The mineral composition of the Opalinus Clay has been analysed by various groups (e.g. Mazurek 1999). In general, the shaly and sandy lithofacies display a qualitatively similar mineral composition. The shaly facies contains more clay minerals and less quartz compared to the sandy facies. The carbonate-rich sandy facies contains more calcite and quartz, but less clay minerals. Observed minerals are quartz, illite and mixed-layer illite-smectites, kaolinite, chlorite, biotite and muscovite, calcite, aragonite, siderite, dolomite and/or ankerite, albite and/or plagioclase, K-feldspar, pyrite, organic matter, and other accessory minerals such as apatite, celestine, zircon, and monazite. The total dry wt $\%$ of illite, chlorite and kaolinite varies between 8 and $80 \%$, and the mixed-layer illite-smectites varies between 3 and 20\% (Table 1). A best estimate of the total clay content is $66 \%$, with mixed-layer illite-smectites of $10 \%$. Quartz varies between 10 and $44 \%$, with a best estimate of $14 \%$ and carbonate minerals vary between 4 and $57 \%$ with a best estimate of $13 \%$. The best estimate for pyrite is $1.1 \%$ and that for organic carbon is $0.8 \%$. Some secondary minerals have also been detected but not quantified, including celestine and barite in veins, and elemental sulphur. Other phases, namely gypsum and traces of jarosite, have been detected only in material that has been altered by oxidation. The bulk of organic material in the Opalinus Clay is kerogen or other uncharacterised material of terrestrial detrital origin. Organic geochemical indices and biomarkers show that the Opalinus Clay in the Mont
Terri section is thermally immature, having experienced maximum burial temperatures of about $80^{\circ} \mathrm{C}$ during Cretaceous burial (Mazurek et al. 2006), and shows low hydrocarbon source-rock potential.

\subsection{Other key properties of Opalinus Clay}

The Opalinus Clay is an anisotropic material with different properties perpendicular and parallel to bedding. Properties for the shaly and sandy facies are given in Table 2, taking into account parameter values perpendicular and parallel to bedding. These properties were derived from Opalinus Clay at the level of the rock laboratory $(280 \mathrm{~m}$ below surface).

From a hydraulic point of view, the Opalinus Clay is characterized by a very low hydraulic conductivity of $2 \times 10^{-13} \mathrm{~m} \mathrm{~s}^{-1}$. Solute transport is, therefore, mainly controlled by molecular diffusion. This is also confirmed by measured natural chloride and helium $\left({ }^{4} \mathrm{He}\right)$ concentrations in the pore-water (Pearson et al. 2003). Chloride and helium concentrations in the pore-waters of Opalinus Clay and its bounding aquifer formations show smooth, regular profiles with depth, with some profiles being more symmetric than the others. When modelling these profiles taking into account the local erosion pattern, it was assumed that the upper aquifer in the Passwang formation was activated first, followed by the lower aquifer in the Staffelegg formation. The best interpretation, which includes this concentration pattern, is the process of molecular diffusion whereby solutes in the Opalinus Clay have diffused into the bounding aquifers (Mazurek and de Haller 2017). Also migration experiments with artificial non- to low-sorbing radionuclides in the Mont Terri rock laboratory confirm solute transport by molecular diffusion,

Table 1 Mineralogy of Opalinus Clay

\begin{tabular}{|c|c|c|c|}
\hline Mineralogy & Shaly facies (wt \%) & Sandy facies (wt $\%$ ) & Carbonate-rich sandy facies (wt\%) \\
\hline \multicolumn{4}{|l|}{ Clay minerals } \\
\hline Illite, chlorite, kaolinite & $39-80$ & $29-70$ & $8-45$ \\
\hline Illite/smectite mixed-layers & $5-20$ & $5-15$ & $3-8$ \\
\hline Quartz & $10-27$ & $22-44$ & $22-36$ \\
\hline \multicolumn{4}{|l|}{ Carbonates } \\
\hline Calcite, dolomite, aragonite, ankerite, siderite & $4-35$ & $11-25$ & $34-57$ \\
\hline \multicolumn{4}{|l|}{ Feldspars } \\
\hline Albite, K-feldspar & $0.3-5$ & $0.2-6$ & $3-11$ \\
\hline Pyrite & $0.9-1.4$ & $1-1.2$ & $0.2-0.5$ \\
\hline Organic matter & $0.8-1.4$ & - & - \\
\hline \multicolumn{4}{|l|}{ Accessory minerals } \\
\hline Apatite, celestine, zircon, monazite & $<0.1$ & $<0.1$ & $<0.1$ \\
\hline
\end{tabular}

The mineral compositions are presented for the shaly, sandy, and the carbonate-rich sandy facies. Values are given in wt $\%$ 
Table 2 Selected in-situ and laboratory-derived key parameters for the Opalinus Clay in and around the Mont Terri rock laboratory (after Jaeggi and Bossart 2014)

\begin{tabular}{|c|c|c|c|c|}
\hline \multirow[b]{2}{*}{ Parameter } & \multicolumn{2}{|l|}{ Shaly facies ${ }^{a}$} & \multicolumn{2}{|c|}{ Sandy facies } \\
\hline & Range & $\begin{array}{c}\text { Best } \\
\text { estimate }\end{array}$ & Range & $\begin{array}{c}\text { Best } \\
\text { estimate }\end{array}$ \\
\hline Density (humid) $\left[\mathrm{g} / \mathrm{cm}^{3}\right]$ & $2.40-2.53^{a}(239)$ & 2.45 & $2.42-2.63^{d}(65)$ & 2.52 \\
\hline Total (physical) porosity [Vol \%] & $14-25^{a}(17)$ & 18 & $5.3-17.7^{\mathrm{d}}(17)$ & 11.1 \\
\hline Water loss porosity [Vol \%] & $13-21^{a}$ & 16 & $4.9-17.5^{d}(19)$ & 10.5 \\
\hline Water content [weight \%] & $5.0-8.9^{a}(22)$ & 6.6 & $2-6^{\circ}(112)$ & 4 \\
\hline Seismic P-wave velocity $\mathrm{Vp}(\mathrm{N})[\mathrm{m} / \mathrm{s}]$ & $2220-3020^{\mathrm{a}}$ & 2620 & $1470-4610^{e}(61)$ & 3280 \\
\hline Seismic P-wave velocity Vp (P) $[\mathrm{m} / \mathrm{s}]$ & $3170-3650^{a}(111)$ & 3410 & $2870-5940^{\circ}(112)$ & 3860 \\
\hline Hydraulic conductivity (N) [m/s] & $2 \mathrm{E}-14-1 \mathrm{E}-12^{\mathrm{a}}$ & $2 \mathrm{E}-13$ & $1 \mathrm{E}-13-5 \mathrm{E}-12^{\mathrm{f}}(10)$ & $1 \mathrm{E}-12$ \\
\hline Specific storage $\left[\mathrm{m}^{-1}\right]$ & $1 \mathrm{E}-7-1 \mathrm{E}-4^{\mathrm{a}}(6)$ & $2 \mathrm{E}-6$ & $1 E-6-1 E-5^{g}(4)$ & $7 \mathrm{E}-6$ \\
\hline $\begin{array}{l}\text { Effective diffusion coefficient }(\mathrm{P}) \\
\begin{aligned}- & \text { Tritiated water HTO }\left[\mathrm{m}^{2} / \mathrm{s}\right] \\
- & \text { Iodine }\left[\mathrm{m}^{2} / \mathrm{s}\right]\end{aligned}\end{array}$ & $\begin{array}{l}4.0 \mathrm{E}-11-6.8 \mathrm{E}-11^{\mathrm{b}} \\
1.0 \mathrm{E}-11-3.0 \mathrm{E}-11^{\mathrm{b}}\end{array}$ & $\begin{array}{l}5.4 \mathrm{E}-11 \\
2.0 \mathrm{E}-11\end{array}$ & - & - \\
\hline $\begin{array}{ll}\text { Effective diffusion coefficient }(\mathrm{N}) \\
\begin{array}{cl}- & \text { Tritiated water HTO }\left[\mathrm{m}^{2} / \mathrm{s}\right] \\
- & \text { Iodine }\left[\mathrm{m}^{2} / \mathrm{s}\right]\end{array}\end{array}$ & $\begin{array}{l}7.1 \mathrm{E}-12-1.1 \mathrm{E}-11^{\mathrm{b}} \\
2.3 \mathrm{E}-12-4.2 \mathrm{E}-12^{\mathrm{b}}\end{array}$ & $\begin{array}{l}1.0 \mathrm{E}-11 \\
3.0 \mathrm{E}-12\end{array}$ & - & - \\
\hline $\begin{array}{l}\text { Effective porosity } \\
\qquad \begin{array}{cl}\text { - } & \text { Tritiated water HTO [\%] } \\
- & \text { Iodine [\%] }\end{array}\end{array}$ & $\begin{array}{l}12.0-16.4^{\mathrm{b}} \\
5.0-12.5^{\mathrm{b}}(5)\end{array}$ & $\begin{array}{l}15.0 \\
8.5\end{array}$ & - & - \\
\hline Uniaxial compressive strength, UCS (N) [MPa] & $5-10^{\circ}(19)$ & 7 & $6-37^{e}(51)$ & 16 \\
\hline Uniaxial compressive streng th, UCS $(\mathrm{P})[\mathrm{MPa}]$ & $4-17^{a}(22)$ & 10.5 & $4-37^{\circ}(60)$ & 18.0 \\
\hline Elastic module, E-module (N) [GPa] & $2.1-3.5^{\mathrm{a}}(34)$ & 2.8 & $0.4-19.0^{\circ}(51)$ & 6.0 \\
\hline Elastic module, E-module (P) [GPa] & $6.3-8.1^{a}(39)$ & 7.2 & $2.0-36.7^{\circ}(60)$ & 13.8 \\
\hline Poisson ratio (N) [-] & $0.28-0.38^{a}(73)$ & 0.33 & $0.06-0.42^{e}(51)$ & 0.22 \\
\hline Poisson ratio (P) [-] & $0.16-0.32^{a}(73)$ & 0.24 & $0.13-1.23^{\mathrm{e}}(59)$ & 0.44 \\
\hline Thermal conductivity $(\mathrm{N})\left[\mathrm{Wm}^{-1} \mathrm{~K}^{-1}\right]$ & & 1.2 & - & - \\
\hline Thermal conductivity $(\mathrm{P})\left[\mathrm{Wm}^{-1} \mathrm{~K}^{-1}\right]$ & & 2.1 & - & - \\
\hline Heat capacity $\left[\mathrm{JKg}^{-1} \mathrm{~K}^{-1}\right]$ & - & $1000^{h}$ & - & - \\
\hline Porewater composition & $\mathrm{Na}-\mathrm{Cl}-\mathrm{SO}$ & ore water $\mathrm{v}$ & th TDS of $18.3 \mathrm{~g} / \mathrm{l}^{\mathrm{i}}$ & \\
\hline $\begin{array}{l}\text { Total cation exchange capacity } \mathrm{CEC} \mathrm{(Co-} \\
\text { Hexamin, } \mathrm{Ni} \text {-en in bold) [meq } 100 \mathrm{~g} \text { rock] }\end{array}$ & $\begin{array}{c}9.4-13.4^{2}(24) \\
-\end{array}$ & $\begin{array}{c}11.1 \\
16(24)\end{array}$ & $7.3-21.9^{j}(13)$ & 14.4 \\
\hline Gas entry pressure [MPa] & $1.2-3.2^{\mathrm{k}}(11)$ & $1.8-2.5$ & - & - \\
\hline
\end{tabular}

The table is ordered into petrophysical (orange), hydraulic (blue), rock-mechanical (grey), thermal (red), and geochemical parameters (yellow, green). Parameters are provided for the ranges and best estimates for the shaly and sandy facies. The number of parameter values, if available, are indicated in parenthesis. Note that currently not all parameters are available for both facies types, e.g. molecular diffusion and thermal parameters are only available for the shaly facies.

Parameters are distinguished for anisotropy by $(\mathrm{N})$ samples normal to bedding, and (P) samples parallel to bedding. The petrophysical and rockmechanical parameters originate mainly from drillcore measurements in the laboratory. Parameter values for the shaly facies are partly derived from ${ }^{a}$ Bossart et al. (2008). The effective diffusion coefficients and effective porosities of the shaly facies are derived in situ and come from ${ }^{b}$ Leupin et al. (2017a). The uniaxial compressive strength (UCS) values of the shaly facies normal to bedding come from ${ }^{\mathrm{c}}$ Amann et al. (2011a, b). The petrophysical and rock-mechanical parameters of the sandy facies come from ${ }^{\mathrm{d}}$ Peters et al. (2011) and ${ }^{\mathrm{e}} \mathrm{Gschwind}(2013)$. In-situ derived hydraulic conductivities of the sandy facies come from ${ }^{\mathrm{f}}$ Lavanchy and Mettier (2012). The specific storage for the sandy facies are derived from ${ }^{\mathrm{g}} \mathrm{Yu}$ et al. (2017). The heat capacity for the shaly facies come from ${ }^{\mathrm{h}}$ Garitte et al. (2014). Pore-water compositions with total dissolved solids originate from ${ }^{i}$ Pearson et al. (2003). The total cation exchange capacity for the sandy facies has been derived by ${ }^{\mathrm{j}}$ Lerouge et al (2011). The in-situ derived gas-entry pressure of the shaly facies originates from ${ }^{\mathrm{k}}$ Miehe et al. (2010). The seismic P-wave velocity values in this table were derived from drillcore measurements in the laboratory; in-situ derived P-wave velocities are provided by Schuster et al. (2017) 
providing diffusion parameters such as diffusion coefficients parallel and normal to bedding, effective porosities, and retardation parameters for sorbing radionuclides (Leupin et al. 2017a). As indicated in Table 2, these diffusion parameters can vary considerably and have to be evaluated separately for every species. This can be illustrated when comparing the parameters of non-sorbing tritiated water (HTO) and iodine: the effective diffusion coefficient of HTO parallel to bedding is $5.4 \times 10^{-11} \mathrm{~m}^{2} \mathrm{~s}^{-1}$, with an effective porosity of $15 \%$, which is about equal to the water loss porosity of $16 \%$. The effective diffusion coefficient of iodide parallel to bedding is $2.0 \times 10^{-11} \mathrm{~m}^{2} \mathrm{~s}^{-1}$ (less than half of that of HTO), with an effective porosity of only $8.5 \%$, which is about half of the water-loss porosity. One reason for these different parameter values lies in the pore-space geometry of Opalinus Clay. The mean pore diameter is 40 nanometres, and the rather large iodine ions can access only about half of the total pore-space, whereas the rather small HTO molecules can access almost the whole pore-space.

From a rock-mechanical point of view, the Opalinus Clay can be considered as a transverse isotropic material (Bock 2009) with a best estimate of uniaxial compressive strength (UCS) for the shaly facies, parallel to bedding of $10.5 \mathrm{MPa}$, Poisson ratio of 0.24 , and Young's modulus of $7.2 \mathrm{GPa}$. These mechanical parameters show rather different values in the sandy facies (Table 2). Generally, Opalinus Clay exhibits a quite complex rheological behaviour, which includes anisotropy, plasticity, and damage (Parisio 2016).

Thermal parameters were estimated only for the shaly facies. With a relatively low mean thermal conductivity of $1.8 \mathrm{~W} \mathrm{~m}^{-1} \mathrm{~K}^{-1}$ and a heat capacity of $1000 \mathrm{~J} \mathrm{~kg}^{-1} \mathrm{~K}^{-1}$ (Garitte et al. 2014), increased geothermal gradients are observed between bottom and top of the Opalinus Clay.

From a geochemical point of view, the pore-water is of $\mathrm{Na}-\mathrm{Cl}-\mathrm{SO}_{4}$ type with a maximum of total dissolved solids (TDS) of $18.3 \mathrm{~g} \mathrm{l}^{-1}$, exhibiting a sea-water signature on the $\mathrm{Cl}^{-} / \mathrm{Br}^{-}$plot and a cation exchange capacity $\left.\mathrm{CEC}\right)(\mathrm{Ni}-$ en) of $11.1 \mathrm{meq} / 100 \mathrm{~g}$ rock (Table 2). The age of this marine pore-water in the region of the Mont Terri anticline is much younger than the sedimentation age of Opalinus Clay (174 Ma). Researchers applied two approaches to date pore-waters: Clauer et al. (2017) interpreted strontium isotope ratios of calcite from the matrix, veins, and fault gouges of the Opalinus Clay to yield an upper Eocene age of 38-36 Ma; Mazurek and de Haller (2017) analysed data on the geochemical evolution of pore-waters in and around Mont Terri giving a slightly younger age, close to the Oligocene/Miocene boundary at ca. 23 Ma. Both teams interpret these findings as marine incursions into the region of the future folded Jura of upper Eocene and Oligocene/ Miocene ages, respectively.
Opalinus Clay also has the property of self-sealing, which means that cracks and fissures of the excavation damaged zone (EDZ) close when moisture is provided. Fractures in the EDZ, stress or anisotropy-induced, have the potential to act as preferential flow paths for radionuclides from the repository site to the biosphere. Thus, sealing of these fractures, especially when exhibiting an interconnected fracture network, is essential in order to reduce transmissivity of the EDZ network and thus to prevent any advective flow from the repository to the biosphere. This self-sealing propriety is mainly due to the mixed-layer illite-smectite clay minerals, which are present in both the shaly and sandy facies, and which swell when moisture is provided. This might be not true for the carbonate-rich sandy facies, where mixed-layer illite-smectite contents are small (Table 1). More detailed information about the parameters of the Opalinus Clay is given in Bossart and Thury (2008).

\section{Thematic overview of experiments}

\subsection{Research topics focussed from 1996 to 2016}

The Mont Terri research programme between 1996 and 2016 consists of 138 individual experiments; 93 experiments were successfully completed by mid-2016, and 45 experiments are still in progress (a compilation of these 138 experiments is presented in Online Resources 8 and 9). The three basic aims of these 138 experiments were and are: (1) understanding the characteristics, processes and mechanisms in undisturbed claystones, (2) understanding the repository-induced perturbations, and (3) performing experiments related to the demonstration of repository implementation technology. It is important to note that these experiments provide data and arguments that are relevant for the performance assessment of a repository and its safety case, but the performance of a repository cannot be directly tested in a generic rock laboratory like Mont Terri.

\subsubsection{Experiments on characteristics, processes and mechanisms in undisturbed claystones}

These experiments include:

- improving drilling and excavation technologies, and testing and sampling methods with the aim of minimising rock perturbations,

- estimating hydrogeological, rock mechanical, and geochemical parameters of the undisturbed Opalinus Clay, including upscaling parameters from laboratory to in situ scale ( $\mathrm{m}$ to $100 \mathrm{~m}$ range), 
- identifying geochemistry of pore-water and natural gases; gaining a better understanding of pore-water origin, dating, and its evolution over geological timescales; and assessment of long-term hydraulic transients associated with basin inversion, erosion, and thermal scenarios,

- experimental work associated with understanding diffusive mass transport in the far-field (kilometre scale, timescale of several millions of years), mainly by measuring and interpreting natural tracer profiles in and around the Mont Terri rock laboratory,

- experimental work associated with the evaluation of diffusion and retention parameters for long-lived radionuclides in the near-field (centimetre to decimetre scale, timescale of $1-5$ years), by artificially placing radionuclides into boreholes, letting them diffuse into the borehole wall, and then analysing the distribution of radionuclides in the overcores.

The latter two points are crucial to assessing the significance of mass transport and they also provide evidence on the degree to which this is diffusion dominated. A transport regime that is diffusion dominated is preferred for long-term radioactive waste isolation and containment. Our strong evidence that mass transfer in a natural claystone barrier such as the Opalinus Clay is diffusion dominated provides an important argument supporting the safety case of a repository in this lithology.

\subsubsection{Experiments on repository-induced perturbations}

These include:

- hydro-mechanical coupled processes (e.g. stress redistributions and pore pressure evolution during mine-by testing),

- thermo-hydro-mechanical-chemical coupled processes (e.g. heating of bentonite and host rock),

- self-sealing processes in the excavation damaged zone, from small scale to repository scale,

- gas-induced transport of radionuclides in pore-water, gas transport along interfaces in the engineered barrier system,

- influence of cement rock liner on the bentonite backfill, buffering potential of the claystone in the near field, and its geochemical and kinetic processes.

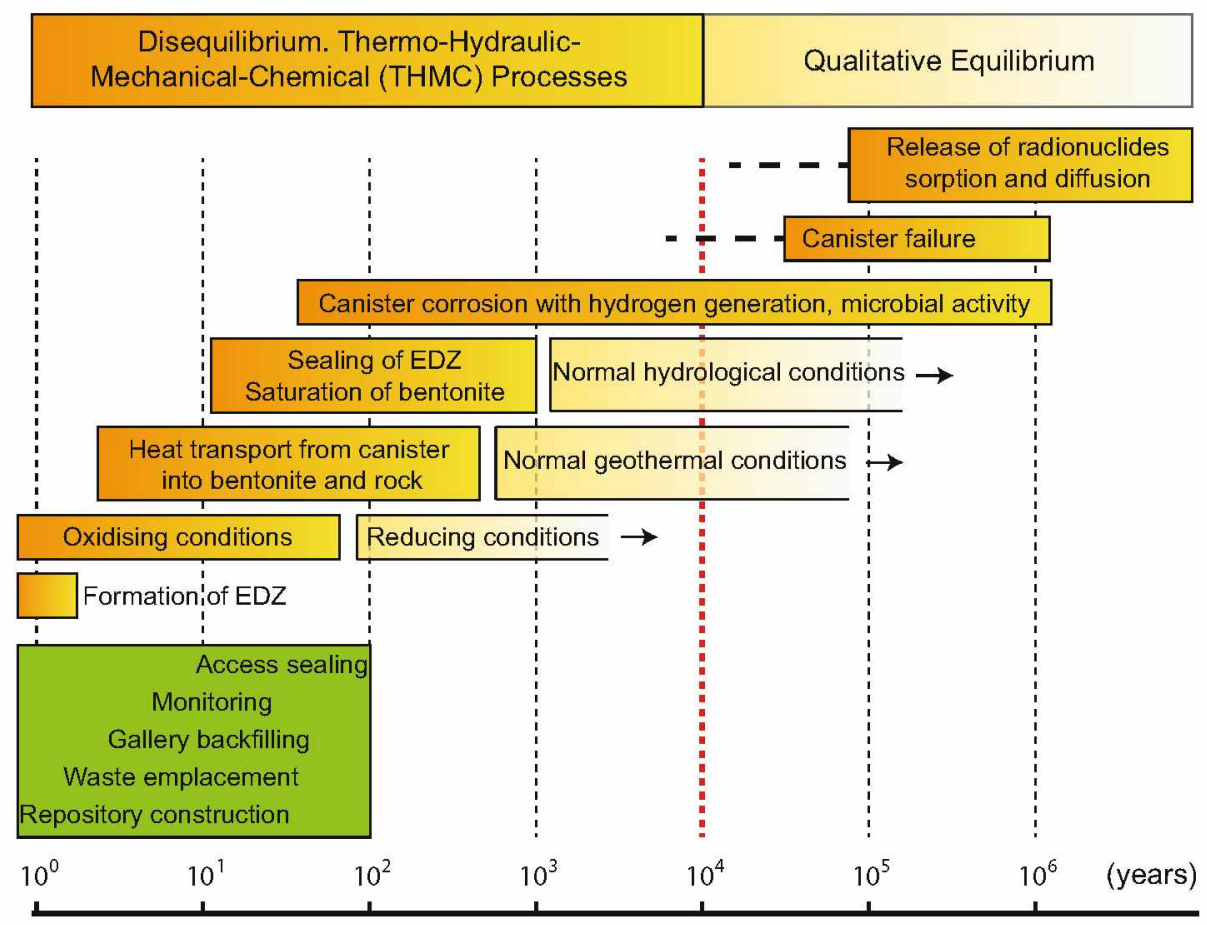

Fig. 5 The possible evolution of a potential high-level waste repository in the Opalinus Clay based on the Swiss disposal concept. Indicated in green are the human engineering activities starting with the construction of a repository until its sealing at the end (the time periods are best estimates and may differ considerably, depending on future decisions by the implementer, safety organisation, and authorities). The expected processes during the lifespan of a repository are given in orange (disequilibrium) grading to yellow (equilibrium), starting with the formation of the excavation damaged zone (EDZ) and ending with the release of radionuclides from breached canisters. Thermo-hydraulic-mechanical and chemical equilibrium is assumed to occur after 10,000 years (see red line) 


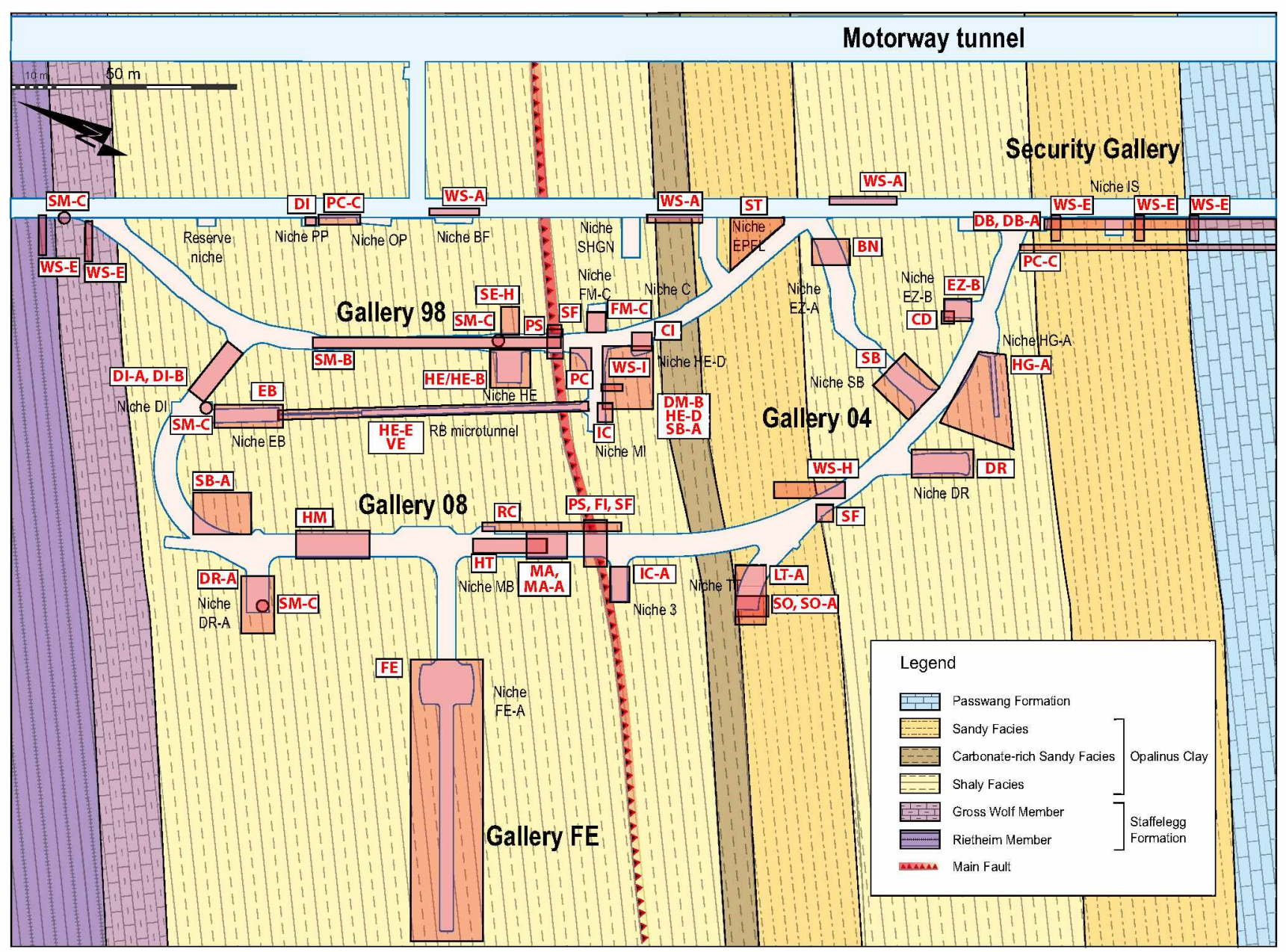

Experiments discussed in Special Issue

$\begin{array}{llll}\text { BN } & \text { Bitumen-nitrate-clay interaction } & \text { HT } & \text { Hydrogen transfer } \\ \text { CD } & \text { Cyclic deformations } & \text { IC } & \begin{array}{l}\text { Iron corrosion of Opalinus Clay } \\ \text { Corrosion of iron in bentonite }\end{array} \\ \text { CI } & \text { Cement-clay interaction } & \text { IC-A } & \text { Long-term monitoring of parameters } \\ \text { DB } & \text { Deep inclined borehole through the Opalinus Clay } & \text { LP-A } & \text { (porewater pressures) } \\ \text { DB-A } & \text { Porewater characterisation-Benchmarking } & & \text { Clay properties, analyses of labtesting } \\ \text { DI } & \text { Diffusion in rock } & \text { MA } & \text { Microbial activity in Opalinus Clay } \\ \text { DI-A } & \text { Long-term diffusion } & \text { MA-A } & \text { Modular platform for microbial studies } \\ \text { DI-B } & \text { Long-term diffusion } & \text { PC } & \text { Porewater chemistry } \\ \text { DM-B } & \text { Long-term deformation measurements } & \text { PC-C } & \text { Gas porewater equilibrium } \\ \text { DR } & \text { Diffusion and retention experiment } & \text { PS } & \text { Petrofabric and strain determination } \\ \text { DR-A } & \text { Diffusion, retention and perturbations } & \text { RC } & \text { Rock mass characterisation } \\ \text { EB } & \text { Engineered barriers } & \text { SB } & \text { Selfsealing barriers clay - sand mixtures } \\ \text { EZ-B } & \text { Fracture generation } & \text { SB-A } & \text { Borehole sealing experiment } \\ \text { FE } & \text { Full scale emplacement demonstration } & \text { SE-H } & \text { Self-sealing with heat (Timodaz) } \\ \text { FI } & \text { Fluid-mineral interactions in Opalinus Clay during } & \text { SF } & \text { Self-sealing of tectonic faults } \\ & \text { natural faulting and heating } & \text { SM-B } & \text { High resolution seismic monitoring } \\ \text { FM-C } & \text { Flow mechanism (tracer) } & \text { SM-C } & \text { Permanent nanoseismic monitoring } \\ \text { HE/HE-B } & \text { Heater experiments I and II } & \text { SO } & \text { Sedimentology of Opalinus Clay } \\ \text { HE-D } & \text { THM behaviour of host rock (heater test) } & \text { SO-A } & \text { Palynology of the Opalinus Clay } \\ \text { HE-E } & \text { In-situ heater test in VE microtunnel } & \text { ST } & \text { Seismic transmission measurements } \\ \text { HG-A } & \text { Gas path host rock \& seals } & \text { VE } & \text { Ventilation test } \\ \text { HM } & \text { Experimental lab investig. on HM-coupled } & \text { WS-A/E/H/l Porewater profiles, wet spots }\end{array}$


4Fig. 6 Compilation of the 43 key experiments in the Mont Terri rock laboratory treated in the following papers of this Special Issue. The sites are shown in the map above and titles and abbreviations of the corresponding experiments are listed below. Only a subset of the Mont Terri experimental portfolio (138 experiments) is shown here. The complete experiment portfolio is presented in the electronic supplementary material (Online Resources 8 and 9)

\subsubsection{Experiments related to the demonstration of repository implementation technology}

These experiments comprise:

- construction and installation of engineered barriers on a $1: 1$ scale,

- horizontal emplacement of canisters and bentonite buffer of the space between canister and claystone,

- evaluation of corrosion rate of container materials, resaturation of bentonite buffer under decreasing heat transport from the canister, and long-term geochemical and microbial evolution of engineered barriers,

- sealing of boreholes and repository access tunnels and shafts, and long-term monitoring of the repository.

We emphasise that not all experiments can be strictly assigned to these three research aims. Some experiments come under two or even three of the aims, depending on the experiment objectives and concepts, and also on the temporal evolution of the experiment.

\subsection{Overview of research and topics presented in the following papers}

\subsubsection{Potential repository evolution}

Experimental results provide input for assessing different phases of repository evolution and performance. A potential repository evolution with causes and effects is shown in Fig. 5, and this will be used to organise the presentation of papers and experiments in the following section (Sect. 3.2.2). This evolution is based on the Swiss concept for high-level radioactive waste disposal in the Opalinus Clay (cf. Nagra 2002). We would like to emphasise that other countries may develop other repository evolution systems based on their own disposal concepts and construction and safety requirements. In the potential repository evolution shown in Fig. 5, we distinguish a transient disequilibration phase and a qualitative equilibrium phase. Qualitative equilibrium does not mean a thermodynamic equilibrium, but rather an equilibrium that can be compared to the one before the repository was constructed. During construction of a repository (a time period of several years), stress redistribution leads to formation of an excavation damaged zone (EDZ) around the access and emplacement galleries. During the operational phase (waste emplacement, buffer emplacement and backfilling, monitoring and sealing: a time period of up to 100 years, green box in Fig. 5), an unsaturated zone will evolve in the near-field due to ventilation, and redox conditions will become oxidizing. In the first few 100 years after closure, significant changes in the repository will occur, including heat transport from the canisters across the bentonite towards the rock, with canister surface temperatures up to $150{ }^{\circ} \mathrm{C}$, and temperatures reaching ca. $90^{\circ} \mathrm{C}$ at the bentonite-rock interface (Nagra 2002). Heat transport into the rock may cause excess pore-water pressures and reduction of effective stresses in the near-field, simply due to the fact that expansion of pore-water is higher than expansion of the rock fabric. As time advances, heat-flow will decrease leading to enhanced saturation in the near-field and swelling of the bentonite buffer. These processes take place concurrently with self-sealing of the EDZ fractures. Both swelling of clay minerals in the EDZ fractures and mechanical fracture closure (swelling bentonite) contribute to self-sealing. Redox conditions in the near-field become clearly reducing and anaerobic corrosion of the steel canisters prevails together with hydrogen production. During this period, microbial activity becomes important: bacteria are involved in redox reactions, degrading hydrogen (porewater sulphates are reduced to sulphides such as $\mathrm{H}_{2} \mathrm{~S}$ ). A sufficiently dense bentonite backfill is used to protect steel canisters from microbial-assisted corrosion. Finally, release of nuclides from the canisters is not expected to occur before some 10,000 years after emplacement. By this time, equilibrium conditions in the claystone are already reestablished and hydraulic and thermal conditions are comparable to those before the repository was constructed. Radionuclide sorption and diffusion into the bentonite and the natural clay barrier is then the final process in the repository evolution, whereby $80 \%$ of the nuclides will be immobilized in the immediate vicinity of the canister.

\subsubsection{The 20 papers and their relation to repository evolution}

The papers in this Special Issue can be linked to the scheme of potential repository evolution shown in Fig. 5 and discussed in the previous section. Altogether, 43 experiments are outlined in the papers, and the location of these is shown in Fig. 6. The results of these experiments are combined and presented in the form of 20 scientific papers according to different themes, often including results from different experiments. The structure of this Special Issue, with the 20 papers organised according to their relevance for different periods of the repository evolution, is shown in Fig. 7. The sequence of the papers as they appear in this issue is given in Table 3, together with their titles and first authors. Figure 6 (location of 


\section{Repository evolution}

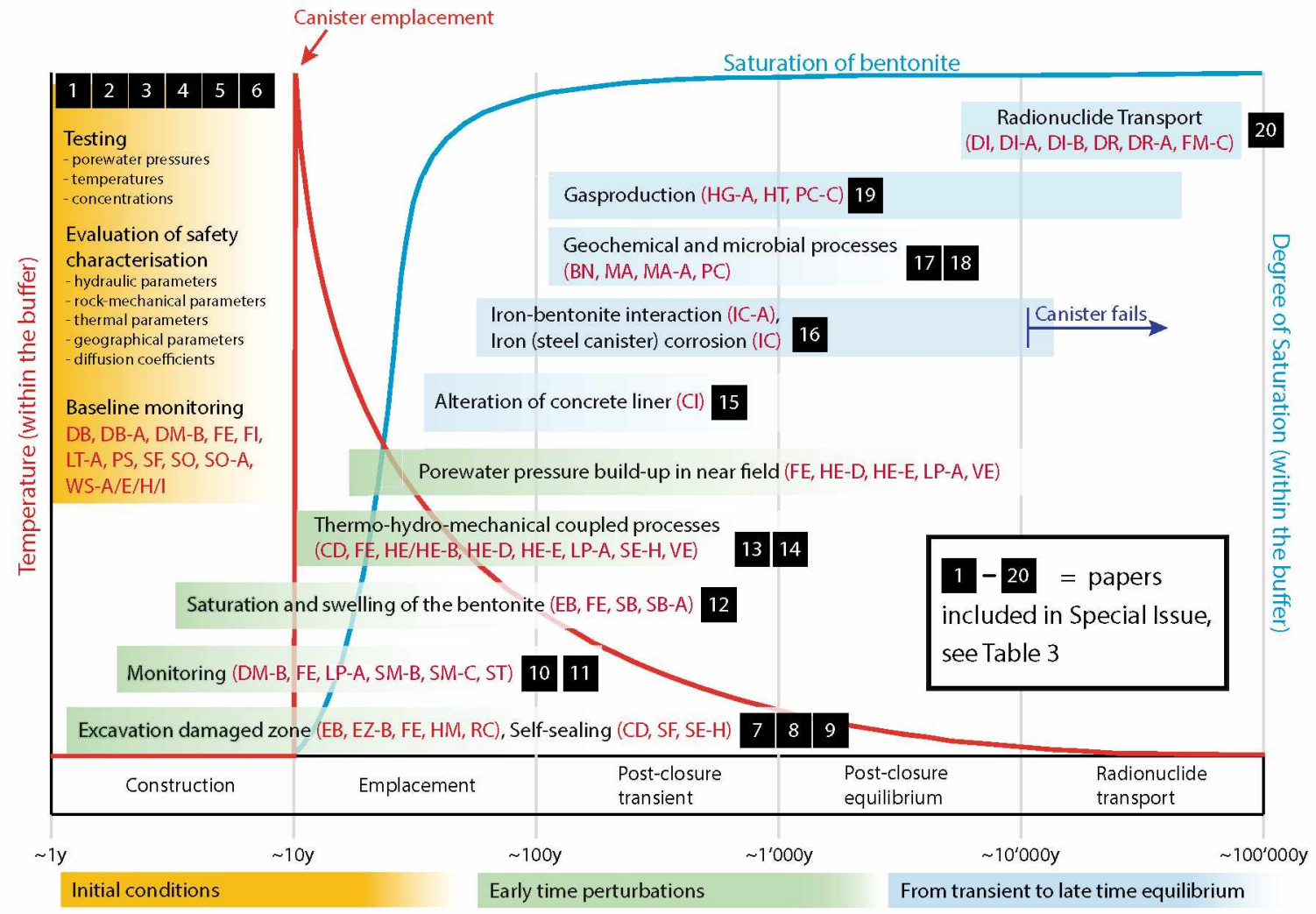

Fig. 7 Repository evolution, key experiments, and related publications in this Special Issue. The repository evolution can be divided into three periods: (1) initial conditions before repository construction (orange), (2) early time perturbations during and shortly after construction (green), and (3) transient to late time (post-closure) equilibrium (blue). The 43 key experiments are indicated as

experiments in the rock laboratory) and Fig. 7 (linking corresponding papers to repository evolution) are thus the key figures and, with Table 3 (paper titles, key experiments, and first authors), they provide a guide and continuous thread for the following 20 papers.

From a practical point of view, only a subset of 43 of the total of 138 experiments is considered here and discussed in this Special Issue. However, this subset of $43 \mathrm{key}$ experiments is characteristic for the total 138 completed and ongoing experiments and gives a comprehensive picture of the whole Mont Terri research programme. The other experiments are documented in internal technical notes, technical reports, and publications. For a complete overview, we refer to the electronically provided supplementary material (Online Resources 8 and 9).

As stated above, we chose the following 20 papers to reflect the different stages of the evolution of a potential repository. This compilation is shown in Fig. 7, where the 43 key experiments in the Mont Terri rock laboratory are abbreviations and refer to Fig. 6 , which shows the complete titles of the key experiments together with their sites. The related publications are shown as black numbers 1-20. An overview of these publications is given in Table 3 . This figure also indicates the temperature (red curve) and degree of saturation (blue curve) within the buffer

related to the three repository phases: initial conditions (orange), early time perturbations (green), and the transient to late time equilibrium phase (blue). The papers in this Special Issue are indicated with black boxes with white numbers and are repeated with the titles and authors in Table 3. Figure 7 also shows two features that are important for the repository evolution: (1) temporal temperature variations in the buffer (red curve), indicating the thermal loading of the disposal system by canister emplacement of highly radioactive waste with a temperature peak and its subsequent temperature decrease, and (2) temporal variations in the degree of buffer saturation (blue curve), indicating the continuous saturation of the bentonite buffer until the time when complete saturation of the buffer and Opalinus Clay in and around the emplacement tunnels is reached.

Alternatively, the 43 key experiments shown in Table 3 and Fig. 6 can be divided into observations over relevant timescales and experiments outside the 
Table 3 List of scientific papers in this Special Issue and abbreviations of key experiments referred to in each paper, numbered in sequence, as shown in Fig. 7 (the detailed key experiment titles and its locations are given in Fig. 6)

\begin{tabular}{|c|c|c|c|}
\hline \# & Paper title & Key experiments & First author \\
\hline \multicolumn{4}{|c|}{ Initial conditions } \\
\hline 1 & $\begin{array}{l}\text { Litho- and biostratigraphy of the Opalinus Clay and bounding formations in the Mont Terri rock laboratory } \\
\text { (Switzerland) }\end{array}$ & SO, SO-A & Bernhard Hostettler (2017) \\
\hline 2 & $\begin{array}{l}\text { Tectonic evolution around the Mont Terri rock laboratory, northwestern Swiss Jura: constraints from kinematic } \\
\text { forward modelling }\end{array}$ & - & $\begin{array}{l}\text { Christophe Nussbaum } \\
(2017)\end{array}$ \\
\hline 3 & Tectonic structure of the "Main Fault" in the Opalinus Clay, Mont Terri rock laboratory (Switzerland) & PS & David Jaeggi (2017) \\
\hline 4 & $\begin{array}{l}\text { Comparative study of methods to estimate hydraulic parameters in the hydraulically undisturbed Opalinus Clay } \\
\text { (Switzerland) }\end{array}$ & DB, DB-A & Catherine Yu (2017) \\
\hline 5 & $\begin{array}{l}\text { Geochemical signature of paleofluids in microstructures from Main Fault in the Opalinus Clay of the Mont Terri } \\
\text { rock laboratory, Switzerland }\end{array}$ & FI, SF & Norbert Clauer (2017) \\
\hline 6 & $\begin{array}{l}\text { Pore-water evolution and solute-transport mechanisms in Opalinus Clay at Mont Terri and Mont Russelin } \\
\text { (Canton Jura, Switzerland) }\end{array}$ & WS-A/E/H/I, SF & Martin Mazurek (2017) \\
\hline \multicolumn{4}{|c|}{ Early time perturbations } \\
\hline 7 & $\begin{array}{l}\text { Geomechanical behaviour of Opalinus Clay at multiple scales: results from Mont Terri rock laboratory } \\
\text { (Switzerland) }\end{array}$ & EZ-B, HM & Florian Amann (2017) \\
\hline 8 & $\begin{array}{l}\text { Hydro-mechanical evolution of the EDZ as transport path for radionuclides and gas: insights from the Mont Terri } \\
\text { rock laboratory (Switzerland) }\end{array}$ & HG-A, EZ-B, SE-H & Paul Marschall (2017) \\
\hline 9 & $\begin{array}{l}\text { Coupled hydraulic-mechanical simulation of seasonally induced processes in the Mont Terri rock laboratory } \\
\text { (Switzerland) }\end{array}$ & CD, LP-A & Gesa Ziefle (2017) \\
\hline 10 & High-resolution mini-seismic methods applied in the Mont Terri rock laboratory (Switzerland) & $\begin{array}{l}\text { DM-B, EB, EZ-B, } \\
\text { HE/HE-B, LT-A, RC, } \\
\text { ST }\end{array}$ & Kristof Schuster (2017) \\
\hline 11 & Seismotectonic analysis around the Mont Terri rock laboratory (Switzerland): a pilot study & SM-B, SM-C & Martinus Abednego (2017) \\
\hline 12 & $\begin{array}{l}\text { In-situ experiments on bentonite-based buffer and sealing materials at the Mont Terri rock laboratory } \\
\text { (Switzerland) }\end{array}$ & $\begin{array}{l}\text { EB, HE-D, HE-E, SB, } \\
\text { SB-A }\end{array}$ & Klaus Wieczorek (2017) \\
\hline 13 & $\begin{array}{l}\text { Performance of the Opalinus Clay under thermal loading: experimental results from Mont Terri rock laboratory } \\
\text { (Switzerland) }\end{array}$ & $\begin{array}{l}\text { HE/HE-B, HE-D, HE- } \\
\text { E, VE }\end{array}$ & Antonio Gens (2017) \\
\hline 14 & Implementation of the full-scale emplacement (FE) experiment at the Mont Terri rock laboratory (Switzerland) & FE & Herwig Mueller (2017) \\
\hline \multicolumn{4}{|c|}{ From transient to late time equilibrium } \\
\hline 15 & 5-Year chemico-physical evolution of concrete-claystone interfaces, Mont Terri rock laboratory (Switzerland) & CI & Urs Maeder (2017) \\
\hline 16 & $\begin{array}{l}\text { Corrosion of carbon steel in clay environments relevant to radioactive waste geological disposals, Mont Terri } \\
\text { rock laboratory (Switzerland) }\end{array}$ & IC, IC-A & Sophia Necib (2017) \\
\hline 17 & Fifteen years of microbiological investigation in Opalinus Clay at the Mont Terri rock laboratory (Switzerland) & MA, MA-A, PC, PC- & Olivier X. Leupin (2017) \\
\hline 18 & $\begin{array}{l}\text { Impact of the electron donor on in situ microbial nitrate reduction in Opalinus Clay: results from the Mont Terri } \\
\text { rock laboratory (Switzerland) }\end{array}$ & BN & Nele Bleyen (2017) \\
\hline 19 & $\begin{array}{l}\text { Natural gas extraction and artificial gas injection experiments in Opalinus Clay Mont Terri rock laboratory } \\
\text { (Switzerland) }\end{array}$ & HT, PC-C & Agnès Vinsot (2017) \\
\hline 20 & $\begin{array}{l}\text { Exploring diffusion and sorption processes at the Mont Terri rock laboratory (Switzerland): lessons learned from } \\
20 \text { years of field research }\end{array}$ & $\begin{array}{l}\text { DI, DI-A, DI-B, DR, } \\
\text { DR-A, FM-C }\end{array}$ & Olivier X. Leupin (2017) \\
\hline
\end{tabular}

The first authors of the corresponding papers are indicated in the last column

observation window. To the first group belong experiments dealing with "initial conditions" such as host-rock characterisation, baseline monitoring, and feasibility experiments, such as construction of emplacement galleries and demonstration of full-scale emplacement. To the second group belong experiments designed to investigate long-term processes on timescales that are not directly accessible through conventional laboratory work. Good examples of this type are diffusion experiments where migration of radionuclides is studied under in situ conditions. The results yield robust transport parameters that are used to calibrate numerical models that simulate mass transport (advective-dispersive-diffusive and reactive transport). Once calibrated, these models can be used to make predictions of radionuclide migration released from a geological repository.

\subsubsection{Rock laboratory and performance of geological repository}

The question whether a rock laboratory like Mont Terri alone is sufficient to assess the performance of a geological repository at a real site can be clearly answered in the negative. As the geological situation at the proposed sites in northern Switzerland will be different (e.g. flat-lying Opalinus Clay with very few faults, different sub-units, confining rocks, stress situation, burial history etc.), additional site-specific investigations are required for developing a repository safety case. The Mont Terri project can, however, deliver strong arguments for a safety case through confident characterisation of properties governing repository evolution, such as the confirmation of diffusive mass transport as the governing transport mechanism in the 
Fig. 8 Diagram showing the four principal contributors to the safety demonstration of a deep geological disposal

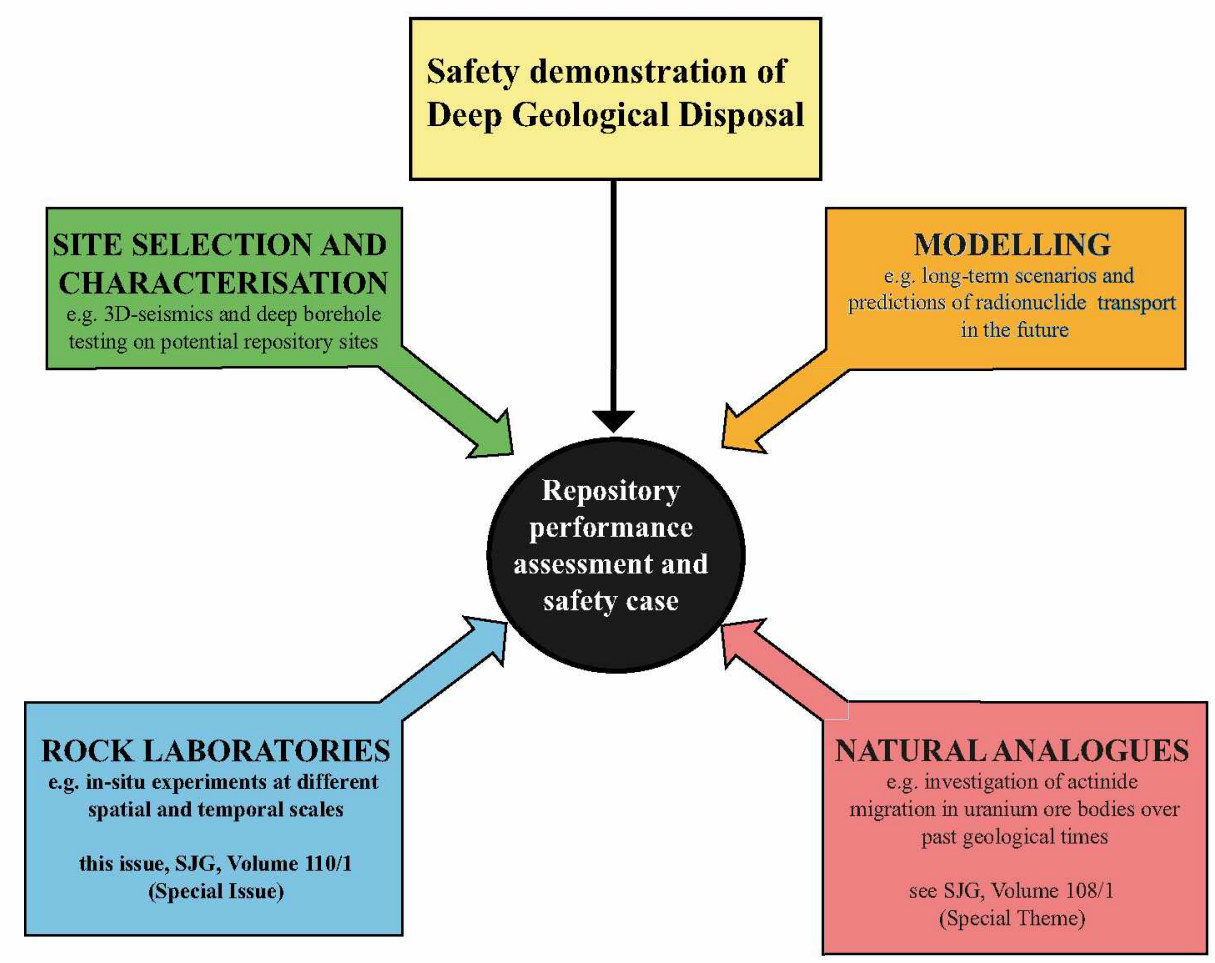

Opalinus Clay over different space and time scales. More information and investigations would be needed for an actual safety case, as e.g. the study of natural analogues (e.g. Alexander et al. 2015), testing of specific sites [with the intention of realising a repository, e.g. Nagra $(2002,2008)]$, and the entire palette of modelling to evaluate long-term scenarios and assess system performance (Fig. 8). Integrating all available information from real and analogue sites, including experimental results obtained from site-specific and generic rock laboratories, is thought to lead to reliable safety demonstrations for deep geological disposal and the development of an appropriate safety case.

Acknowledgements The authors would like to thank the 16 Mont Terri Partner organisations and the European Union for their financial investment into the Mont Terri Project over the past 20 years. The Republic and Canton of Jura as owner of the Opalinus Clay and landlord of the rock laboratory is warmly thanked, especially the Ministers Pierre Kohler, Laurent Schaffter, Philippe Receveur, and David Eray, who all supported the project. The cantonal "Commission de suivi" with its experts, especially Pascal Mertenat, Marcos Buser and Thomas Flüeler, are thanked for lively discussions and for providing us the yearly authorisations. We also thank the three reviewers, Philippe Schaub (SFOE), Russell Alexander (Bedrock Geosciences, Switzerland), and Geoffrey Milnes (Scientific Editor of the SJG) for significantly improving the manuscript. Roy Freeman reviewed the English of the manuscript. Last but not least, we thank
Marc Thury for his foresight and initiative in the early 1990s, which led to the founding of the Mont Terri Project 20 years ago.

Open Access This article is distributed under the terms of the Creative Commons Attribution 4.0 International License (http://crea tivecommons.org/licenses/by/4.0/), which permits unrestricted use, distribution, and reproduction in any medium, provided you give appropriate credit to the original author(s) and the source, provide a link to the Creative Commons license, and indicate if changes were made.

\section{Appendix}

Explanation of acronyms and abbreviations, which are used in this Special Issue.

\begin{tabular}{ll}
\hline $\begin{array}{l}\text { Acronyms and } \\
\text { abbreviations }\end{array}$ & Explanation \\
\hline A & \\
ANDRA & $\begin{array}{c}\text { Agence Nationale pour la gestion des Déchets } \\
\text { Radioactifs, France (French National } \\
\text { Radioactive Waste Management } \\
\text { Organisation) }\end{array}$ \\
APHA & $\begin{array}{c}\text { American Public Health Association } \\
\text { API }\end{array}$ \\
AWWA & American Petroleum Index \\
\hline
\end{tabular}




\begin{tabular}{|c|c|c|c|}
\hline $\begin{array}{l}\text { Acronyms and } \\
\text { abbreviations }\end{array}$ & Explanation & $\begin{array}{l}\text { Acronyms and } \\
\text { abbreviations }\end{array}$ & Explanation \\
\hline \multicolumn{2}{|l|}{ B } & \multicolumn{2}{|l|}{$\mathrm{G}$} \\
\hline BDZ & Borehole damaged zone & $\mathrm{Ga08}$ & Gallery 2008 (Mont Terri rock laboratory) \\
\hline $\mathrm{Bd} Z$ & Borehole disturbed zone & Ga98 & Gallery 1998 (Mont Terri rock laboratory) \\
\hline BGR & $\begin{array}{l}\text { Bundesanstalt für Geowissenschaften und } \\
\text { Rohstoffe, Deutschland (Federal Institute for } \\
\text { Geosciences and Natural Resources, } \\
\text { Germany) }\end{array}$ & $\begin{array}{l}\text { Gl Ltd. } \\
\text { GPa }\end{array}$ & $\begin{array}{l}\text { Granulated Bentonite Mixture, but also } \\
\text { Granular Backfill Material } \\
\text { Geotechnical Institute Limited, Switzerland } \\
\text { Gigapascal }\end{array}$ \\
\hline \multirow{2}{*}{$\begin{array}{l}\text { BIB } \\
\text { BRGM }\end{array}$} & Broad ion beam & GR & Gamma ray \\
\hline & $\begin{array}{l}\text { Bureau de Recherches Géologiques et } \\
\text { Minières, France (French Geological Survey) }\end{array}$ & GRS & $\begin{array}{l}\text { Gesellschaft für Anlagen- und } \\
\text { Reaktorsicherheit gGmbH, Germany }\end{array}$ \\
\hline \multicolumn{2}{|l|}{$\mathrm{C}$} & \multicolumn{2}{|r|}{ 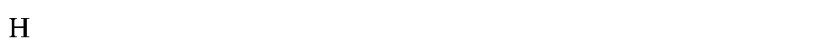 } \\
\hline CEC & Cation exchange capacity & HDO & Hydrodeuteriumoxid \\
\hline Chevron & Chevron Corporation, USA & HLW & High level (radioactive) waste \\
\hline CRIEPI & $\begin{array}{l}\text { Central Research Institute of Electric Power } \\
\text { Industry, Japan }\end{array}$ & $\mathrm{HM}$ & Hydro-mechanical \\
\hline $\begin{array}{l}\text { DAS } \\
\text { DECOVALEX }\end{array}$ & $\begin{array}{l}\text { Data acquisition system } \\
\text { Development of Coupled Models and their }\end{array}$ & HSK/ENSI & $\begin{array}{l}\text { Hauptabteilung für die Sicherheit der } \\
\text { Kernanlagen (until 2008), Eidgenössisches } \\
\text { Nuklearsicherheitsinspektorat (Swiss Federal } \\
\text { Nuclear Safety Inspectorate, since 2009) }\end{array}$ \\
\hline DECOVALEX & $\begin{array}{l}\text { Development of Coupled Models and their } \\
\text { Validation against Experiments (project } \\
\text { name) }\end{array}$ & HTO & Tritiated Water \\
\hline DOE/LBNL & \multirow[t]{2}{*}{$\begin{array}{l}\text { Department of Energy/Lawrence Berkeley } \\
\text { National Laboratory, USA }\end{array}$} & IAEA & International Atomic Energy Agency, Austria \\
\hline 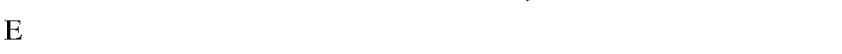 & & IC & Ion chromatography \\
\hline \multirow{4}{*}{$\begin{array}{l}\text { EBS } \\
\text { EDZ } \\
\text { EdZ } \\
\text { EMPA }\end{array}$} & Engineered barrier system & ICP-AES & $\begin{array}{l}\text { Inductively coupled plasma-atomic emission } \\
\text { spectroscopy }\end{array}$ \\
\hline & Excavation damaged zone & \multirow{2}{*}{$\begin{array}{l}\text { ICP-MS } \\
\text { ICP-OES }\end{array}$} & Inductively coupled plasma-mass spectrometry \\
\hline & Eidgenössische Materialprüfungs- und & & $\begin{array}{l}\text { Inductively COUPLED PLASMA-OPTICAL } \\
\text { EMISSION SPECTROSCOPY }\end{array}$ \\
\hline & $\begin{array}{l}\text { Forschungsanstalt, Schweiz (Swiss Federal } \\
\text { Laboratories for Materials Science and } \\
\text { Technology) }\end{array}$ & $\begin{array}{l}\text { ILW } \\
\text { IRSN }\end{array}$ & $\begin{array}{l}\text { Intermediate level (radioactive) waste } \\
\text { Institut de Radioprotection et de Sûreté }\end{array}$ \\
\hline \multirow[t]{2}{*}{ ENRESA } & \multirow{2}{*}{$\begin{array}{l}\text { Empresa Nacional de Residuos Radiactivos } \\
\text { S.A., España (Spanish National Radioactive } \\
\text { Waste Management Organisation) }\end{array}$} & & $\begin{array}{l}\text { Nucléaire, France (French Institute for } \\
\text { Radiological Protection and Nuclear Safety) }\end{array}$ \\
\hline & & ISRM & International Society for Rock Mechanics \\
\hline ENSI & $\begin{array}{l}\text { Eidgenössisches Nuklearsicherheitsinspektorat, } \\
\text { Schweiz (Swiss Federal Nuclear Safety } \\
\text { Inspectorate, Switzerland) }\end{array}$ & IVM & Interval velocity measurements \\
\hline EPFL & $\begin{array}{l}\text { École Polytechnique Fédérale de Lausanne, } \\
\text { Suisse (Swiss Federal Institute of } \\
\text { Technology, Lausanne, Switzerland) }\end{array}$ & $\begin{array}{l}\text { JU } \\
\text { JU-cant. }\end{array}$ & $\begin{array}{l}\text { Japan Atomic Energy Agency, Japan } \\
\text { Jura (Canton) } \\
\text { Laboratoire cantonal jurassien accrédité }\end{array}$ \\
\hline ESDRED & $\begin{array}{l}\text { Engineering Studies and Demonstration of } \\
\text { Repository Designs (EC project) }\end{array}$ & & Switzerland) \\
\hline $\begin{array}{l}\text { ESM } \\
\text { ETH }\end{array}$ & $\begin{array}{l}\text { Electronic Supplementary Material } \\
\text { Eidgenössische Technische Hochschule in } \\
\text { Zürich, Schweiz (Swiss Federal Institute of } \\
\text { Technology, Zurich, Switzerland) }\end{array}$ & JU-ENV & $\begin{array}{l}\text { Office de l'Environnement, Canton du Jura } \\
\text { (Office for the Environment, Canton of Jura, } \\
\text { Switzerland) }\end{array}$ \\
\hline $\begin{array}{l}\text { EURATOM } \\
\text { F }\end{array}$ & $\begin{array}{l}\text { Zürich, Schweiz (Swiss Federal Institute of } \\
\text { Technology, Zurich, Switzerland) } \\
\text { European Atomic Energy Community }\end{array}$ & JU-OEPN & $\begin{array}{l}\text { Office des Eaux et de la Protection de la } \\
\text { Nature, Canton du Jura (Office for Water and } \\
\text { Protection of Nature, Canton of Jura, } \\
\text { Switzerland) }\end{array}$ \\
\hline $\begin{array}{l}\text { FANC } \\
\text { FEDRO }\end{array}$ & $\begin{array}{l}\text { Federal Agency for Nuclear Control, Belgium } \\
\text { Federal Roads Office, Switzerland }\end{array}$ & JU-SIN & $\begin{array}{l}\text { Service des Infrastructures, Canton du Jura } \\
\text { (Office for Infrastructure, Canton of Jura, } \\
\text { Switzerland) }\end{array}$ \\
\hline FIB & Focused ion beam & $\mathrm{K}$ & \\
\hline FORGE & Fate of Repository Gases (EC project) & $\mathrm{kPa}$ & Kilopascal \\
\hline FOWG & $\begin{array}{l}\text { Federal Office for Water and Geology, } \\
\text { Switzerland (until 2005) }\end{array}$ & $\mathrm{L}$ & \\
\hline
\end{tabular}




\begin{tabular}{|c|c|}
\hline $\begin{array}{l}\text { Acronyms and } \\
\text { abbreviations }\end{array}$ & Explanation \\
\hline LLW & Low-Level (radioactive) waste \\
\hline LUCOEX & $\begin{array}{l}\text { Large Underground Concept Experiments (EC } \\
\text { project) }\end{array}$ \\
\hline \multicolumn{2}{|l|}{ M } \\
\hline Ma & Million years \\
\hline meq $\%$ & Milliequivalent \% \\
\hline MPa & Megapascal \\
\hline Myr & Million years (duration) \\
\hline \multicolumn{2}{|l|}{$\mathrm{N}$} \\
\hline Nagra & $\begin{array}{l}\text { Nationale Genossenschaft für die Lagerung } \\
\text { radioaktiver Abfälle, Schweiz (National } \\
\text { Cooperative for the Disposal of Radioactive } \\
\text { Waste, Switzerland) }\end{array}$ \\
\hline Ni-en & Nickelethylenediamine solution \\
\hline NNL & National Nuclear Laboratory, UK \\
\hline NWMO & $\begin{array}{l}\text { Nuclear Waste Management Organisation, } \\
\text { Canada }\end{array}$ \\
\hline \multicolumn{2}{|l|}{$\mathrm{O}$} \\
\hline OBI & Optical borehole imager \\
\hline OECD-NEA & $\begin{array}{l}\text { Organisation for Economic Co-operation and } \\
\text { Development-Nuclear Energy Agency }\end{array}$ \\
\hline OPC & Ordinary Portland cement \\
\hline \multicolumn{2}{|l|}{$\mathrm{P}$} \\
\hline PEPS & $\begin{array}{l}\text { Long-term performance of the Engineered } \\
\text { Barrier Systems (EC project) }\end{array}$ \\
\hline \multicolumn{2}{|l|}{ Q } \\
\hline \multicolumn{2}{|l|}{$\mathrm{R}$} \\
\hline RH & Relative humidity \\
\hline RWTH-Aachen & $\begin{array}{l}\text { Rheinisch-Westfälische Technische } \\
\text { Hochschule-Aachen, Deutschland } \\
\text { (Technical University, Aachen, Germany) }\end{array}$ \\
\hline \multicolumn{2}{|l|}{ S } \\
\hline SCK.CEN & $\begin{array}{l}\text { Studiecentrum voor Kernenergie, Belgium } \\
\text { (Belgian Nuclear Research Centre) }\end{array}$ \\
\hline SEM & Scanning electron microscopy \\
\hline SF/HLW & Spent Fuel/high level waste \\
\hline SFOE & Swiss Federal Office of Energy \\
\hline SGR & Spectral Gamma ray \\
\hline SGS & Swiss Geological Survey \\
\hline SJG & Swiss Journal of Geosciences \\
\hline SNHGS & $\begin{array}{l}\text { Service National Hydrologique et Géologique, } \\
\text { Suisse (former Swiss Geological Survey, } \\
\text { until 2005) }\end{array}$ \\
\hline SRB & Sulphate-reducing bacteria \\
\hline STP & Standard temperature and pressure \\
\hline swisstopo & $\begin{array}{l}\text { Bundesamt für Landestopografie (Federal } \\
\text { Office of Topography, Switzerland) }\end{array}$ \\
\hline \multicolumn{2}{|l|}{$\mathrm{T}$} \\
\hline TDR & Time-domain reflectometry \\
\hline TDS & Total dissolved solids \\
\hline TEM & Transmission electron microscopy \\
\hline
\end{tabular}

\begin{tabular}{ll}
\hline $\begin{array}{l}\text { Acronyms and } \\
\text { abbreviations }\end{array}$ & Explanation \\
\hline TH & Thermo-hydraulic \\
THM & Thermo-hydro-mechanical \\
THMC & Thermo-hydro-mechanical-chemical \\
TIC & Total inorganic carbon \\
TIMODAZ & Thermal Impact on the Damaged Zone (EC \\
& project) \\
TOC & Total organic carbon \\
U & \\
URF & Underground Research Facility \\
URL & Underground Research Laboratory \\
V & \\
W & \\
wt\% & Weight percent \\
X & X-ray diffraction \\
XRD & X-ray fluorescence \\
XRF & \\
$Z$ & Amt für Abfall, Wasser, Energie und Luft, \\
ZH-AWEL & Kanton Zürich (Office for the Environment, \\
& Canton of Zurich, Switzerland) \\
\hline
\end{tabular}

\section{References}

Abednego, M., Blascheck, P., Schefer, S., Mosar, J., Nussbaum, C., Joswig, M., \& Bossart, P. (2017). Seismotectonic analysis around the Mont Terri rock laboratory (Switzerland): a pilot study. Swiss Joumal of Geosciences, 110. doi:10.1007/s00015017-0263-6 (this issue).

Alexander, W. R., Reijonen, H. M., \& McKinley, I. G. (2015). Natural analogues: Studies of geological processes relevant to radioactive waste disposal in deep geological repositories. Swiss Journal of Geosciences, 108, 75-100.

Amann, F., Button, E., Evans, K., Gischig, V., \& Blümel, M. (2011a). Experimental study of the brittle behavior of clay shale in rapid unconfined compression. Rock Mechanics and Rock Engineering, 44(4), 415-430.

Amann, F., Kaiser, P., \& Button, E. (2011b). Experimental study of brittle behavior of clay shale in rapid triaxial compression. Rock Mechanics and Rock Engineering, 45(1), 21-33.

Amann, F., Wild, K. M., Loew, S., Yong, S., Thoeny, R., \& Frank, E. (2017). Geomechanical behaviour of Opalinus Clay at multiple scales: results from Mont Terri rock laboratory (Switzerland). Swiss Journal of Geosciences, 110. doi:10.1007/s00015-0160245-0 (this issue).

Blaesi, H.-R. (1987). Lithostratigraphie und Korrelation der Dogger Sedimente in den Bohrungen Weiach, Riniken und Schafisheim. Eclogae Geologicae Helvetiae, 80, 415-430.

Blaesi, H.-R., Moeri, A., Bossart, P. (1996). Results of the Phase 1 drilling campaign. Mont Terri Technical Report, TR 96-01, p. 54. Federal Office of Topography (swisstopo), Wabern, Switzerland. http://www.mont-terri.ch.

Blaesi, H.-R., Peters, T. J., \& Mazurek, M. (1991). Der Opalinus Clay des Mont Terri (Kanton Jura): Lithologie, Mineralogie und physiko-chemische Gesteinsparameter. Nagra Intemer Bericht, 90-60. Nagra, Wettingen, Switzerland. http://www.nagra.ch. 
Blechschmidt, I., \& Vomvoris, S. (2010). Underground research facilities and rock laboratories for the development of geological disposal concepts and repository systems. In J. Ahn, M. J. Apted, et al. (Eds.), Geological repository systems for safe disposal of spent nuclear fuels and radioactive waste (pp. 83-118). Sawston: Woodhead Publishing Limited.

Bleyen, N., Smets, S., Small, J., Moors, H., Leys, N, Albrecht, A., De Cannière, P., Schwyn, B., Wittebroodt, C., \& Valcke, E. (2017). Impact of the electron donor on in situ microbial nitrate reduction in Opalinus Clay: results from the Mont Terri rock laboratory (Switzerland). Swiss Journal of Geosciences, 110. doi:10.1007/s00015-016-0256-x (this issue).

Bock, H. (2009). RA experiment: Updated review of the rock mechanics properties of the Opalinus Clay of the Mont Terri URL based on laboratory and field testing. Mont Terri Technical Report, TR 08-04, p. 66. Federal Office of Topography (swisstopo), Wabern, Switzerland. http://www.mont-terri.ch.

Bossart, P., \& Thury, M. (2008). Mont Terri Rock Laboratory. Project, Programme 1996-2007 and results. Reports of the Swiss Geological Survey, No. 3, p. 445. Federal Office of Topography (swisstopo), Wabern, Switzerland. http://www.mont-terri.ch.

Caër, T., Maillot, B., Souloumiac, P., Leturmy, P., Frizon de Lamotte, D., \& Nussbaum, C. (2015). Mechanical validation of balanced cross-sections: The case of the Mont Terri anticline at the Jura front (NW Switzerland). Joumal of Structural Geology, 75, 32-38.

Clauer, N., Techer, I., Nussbaum, C., \& Laurich, B. (2017). Geochemical signature of paleofluids in microstructures from Main Fault of the Opalinus Clay of the Mont Terri rock laboratory, Switzerland. Swiss Journal of Geosciences, 110. doi:10.1007/s00015-016-0253-0 (this issue).

Delay, J., Bossart, P., Ling, L. X., Blechschmidt, I., Ohlsson, M., Vinsot, A., et al. (2014). Three decades of underground research laboratories: What have we learned? Geological Society London Special Publications, 400(1), 7-32.

Freivogel, M., \& Huggenberger, P. (2003). Modellierung bilanzierter Profile im Gebiet Mont Terri-La Croix (Kanton Jura). In: P. Heitzmann, \& J.-P. Tripet (Eds.), Mont Terri Project-geology, paleohydrology and stress field of the Mont Terri region (pp. 7-44). Bern: OFEG Report, Geology Serie, No. 4. Federal Office of Topography (swisstopo), Wabern, Switzerland. http://www. mont-terri.ch.

Garitte, B., Gens, A., Vaunat, J., \& Armand, G. (2014). Thermal conductivity of argillaceous rocks: Determination methodology using in situ heating tests. Rock Mechanics and Rock Engineering, 47(1), 111-129.

Gautschi, A., Ross, C., \& Scholtis, A. (1993). Pore watergroundwater relationships in Jurassic shales and limestones of northern Switzerland. In D. A. C. Manning, P. L. Hall, \& C. R. Hughes (Eds.), Geochemistry of clay-pore fluid interactions (pp. 412-422). London: Chapman Hall.

Gens, A., Wieczorek, K., Gaus, I., Garitte, B., Mayor, J.C., Schuster, K., Armand, G., García-Siñeriz, J-L., \& Trick, T. (2017). Performance of the Opalinus Clay under thermal loading: experimental results from Mont Terri rock laboratory (Switzerland). Swiss Journal of Geosciences, 110. doi:10.1007/s00015016-0258-8 (this issue)

Gschwind, S. (2013). The relationship between failure behavior and sedimentary subfacies types in the sandy facies of Opalinus Clay. Master Thesis, Swiss Federal Institute of Technology in Zurich (ETH Zurich), Zurich, Switzerland, p. 170.

Hostettler, B., Reisdorf, A. G., Jaeggi, D., Deplazes, G., Bläsi, H.-R., Morard, A., Feist-Burkhardt, S., Waltschew, A., Dietze, V., \& Menkveld-Gfeller, U. (2017). Litho- and biostratigraphy of the Opalinus Clay and bounding formations in the Mont Terri rock laboratory (Switzerland). Swiss Journal of Geosciences, 110 doi:10.1007/s00015-016-0250-3 (this issue).

IAEA. (2012). The safety case and safety assessment for the disposal of radioactive waste. IAEA Safety Standards Series, Specific Safety Guide No. SSG-23, STI/PUB/1553. International Atomic Energy Agency, Vienna, Austria.

Jaeggi, D., \& Bossart, P. (2014). Kompilation der lithologischen Variabilität und Eigenschaften des Opalinus-Ton im Felslabor Mont Terri. Expert Report for ENSI, 09-08, 66 pp. Federal Office of Topography (swisstopo), Wabern, Switzerland. http:// www.swisstopo.admin.ch.

Jaeggi, D., Laurich, B., Nussbaum, C., Schuster, K., \& Connolly, P. (2017). Tectonic structure of the "Main Fault" in the Opalinus Clay, Mont Terri rock laboratory (Switzerland). Swiss Journal of Geosciences, 110. doi:10.1007/s00015-016-0243-2 (this issue).

Laubscher, H. P. (1963). Geologischer Atlas der Schweiz, Atlasblatt 40, 1085 St. Ursanne-Erläuterungen. Basel: Schweizerische Geotechnische Kommission. Federal Office of Topography (swisstopo), Wabern, Switzerland. http://www.mont-terri.ch.

Lavanchy, J. M., \& Mettier, R. (2012). HA (Hydrogeological analysis) Experiment: Hydraulic database, Phases 1-16, Version 1.0. Mont Terri Technical Note, TN 2010-74, p. 22. Federal Office of Topography (swisstopo), Wabern, Switzerland. http:// www.mont-terri.ch.

Lerouge, C., Blanc, P., Gaboreau, S., Decouchon, E., Guerrot, C., Wille, C., Jean-Prost, E., \& Haas, H. (2011). PC-C experiment: Mineralogy and geochemistry of cores of the BPC-C2 borehole Mont Terri Rock Laboratory-phase II, Final report. Mont Terri Technical Note, TN 2010-05 (rev), p. 61. Federal Office of Topography (swisstopo), Wabern, Switzerland. http://www. mont-terri.ch.

Leupin, O.X., Bernier-Latmani, R., Bagnoud, A., Moors, H., Leys, N., Wouters, K., \& Stroes-Gascoyne, S. (2017a). Fifteen years of microbiological investigation in Opalinus Clay at the Mont Terri rock laboratory (Switzerland). Swiss Journal of Geosciences, 110. doi:10.1007/s00015-016-0255-y (this issue).

Leupin, O.X., Van Loon, L.R., Gimmi, T., Wersin, P., \& Soler, J.M (2017b). Exploring diffusion and sorption processes at the Mont Terri rock laboratory (Switzerland): lessons learned from 20 years of field research. Swiss Journal of Geosciences, 110. doi:10.1007/s00015-016-0254-z (this issue).

Maeder, U., Jenni, A., Lerouge, C., Gaboreau, S., Miyoshi, S., Kimura, Y., Cloet, V., Fukaya, M., Claret, F., Otake, T., Shibata, M., \& Lothenbach, B. (2017). 5-Year chemico-physical evolution of concrete-claystone interfaces, Mont Terri rock laboratory (Switzerland). Swiss Journal of Geosciences, 110. doi:10.1007/ s00015-016-0240-5 (this issue).

Marschall, P., Giger, S., De La Vassière, R., Shao, H., Leung, H., Nussbaum, C., Trick, T., Lanyon, B., Senger, R., Lisjak, A., \& Alcolea, A. (2017). Hydro-mechanical evolution of the EDZ as transport path for radionuclides and gas: insights from the Mont Terri rock laboratory (Switzerland). Swiss Journal of Geosciences, 110. doi:10.1007/s00015-016-0246-z (this issue).

Mazurek, M. (1999). Mineralogy of the Opalinus Clay. In: M. Thury, \& P. Bossart (Eds.), Mont Terri Rock Laboratory. Results of the hydrogeological, geochemical and geotechnical experiments performed in 1996 and 1997. Geological Reports No. 23. Federal Office of Topography (swisstopo), Wabern, Switzerland. http://www.mont-terri.ch.

Mazurek, M., \& de Haller, A. (2017). Pore-water evolution and solute-transport mechanisms in Opalinus Clay at Mont Terri and Mont Russelin (Canton Jura, Switzerland). Swiss Journal of Geosciences, 110. doi:10.1007/s00015-016-0249-9 (this issue).

Mazurek, M., Gautschi, A., Marschall, P., Vigneron, G., Lebon, P., \& Delay, J. (2008). Transferability of geoscientific information 
from various sources (study sites, underground rock laboratories, natural analogues) to support safety cases for radioactive waste repositories in argillaceous formations. Physics and Chemistry of Earth Parts $A / B / C, 33,95-105$.

Mazurek, M., Hurford, A. J., \& Leu, W. (2006). Unravelling the multi-stage burial history of the Swiss Molasse Basin: Integration of apatite fission track, vitrinite reflectance and biomarker isomerisation analysis. Basin Research, 18(1), 27-50.

Miehe, R., Czaikowsik, O., \& Wieczorek, K. (2010). Barrier Integrity of the Isolation Rock Zone in Clay Formations. Mont Terri Technical Note, TN 2010-82, 97 pp. Federal Office of Topography (swisstopo), Wabern, Switzerland. http://www.mont-terri. ch.

Müller, H. R., Garitte, B., Vogt, T., Köhler, S., Sakaki, T., Weber, H. Spillmann, T., Hertrich, M., Becker, J. K., Giroud, N., Cloet, V., Diomidis N., \& Vietor, T. (2017). Implementation of the fullscale emplacement (FE) Experiment at the Mont Terri rock laboratory (Switzerland). Swiss Journal of Geosciences, 110. doi:10.1007/s00015-016-0251-2 (this issue).

Nagra. (2002). Projekt Opalinuston: Konzept für die Anlage und den Betrieb eines geologischen Tiefenlagers: Entsorgungsnachweis für abgebrannte Brennelemente, verglaste hochaktive sowie langlebige mittelaktive Abfälle. Nagra Technical Repart, 02-02, p. 24. Nagra, Wettingen, Switzerland. http://www.nagra. ch.

Nagra. (2008). Entsorgungsprogramm 2008 der Entsorgungspflichtigen. Nagra Technical Report, 08-01, p. 134. Nagra, 5400 Wettingen, Switzerland. http://www.nagra.ch.

Nagra. (2010). Beurteilung der geologischen Unterlagen für die provisorischen Sicherheitsanalysen in SGT Etappe 2. Klärung der Notwendigkeit ergänzender geologischer Untersuchungen. Nagra Technical Report, 10-01, p. 44. Nagra, Wettingen, Switzerland. http://www.nagra.ch.

Necib, S., Diomidis, N., Keech, P., \& Nakayama, M. (2017). Corrosion of carbon steel in clay environments relevant to radioactive waste geological disposals, Mont Terri rock laboratory (Switzerland). Swiss Journal of Geosciences, 110. doi:10. 1007/s00015-016-0259-7 (this issue).

Nussbaum, C., Bossart, P., Amann, F., \& Aubourg, C. (2011). Analysis of tectonic structures and excavation induced fractures in the Opalinus Clay, Mont Terri underground rock laboratory (Switzerland). Swiss Journal of Geosciences, 104, 187-210.

Nussbaum, C., Kloppenburg, A., Caër, T., \& Bossart, P. (2017). Tectonic evolution around the Mont Terri rock laboratory, northwestern Swiss Jura: constraints from kinematic forward modelling. Swiss Journal of Geosciences, 110. doi:10.1007/ s00015-016-0248-x (this issue).

OECD (2013). Underground Research Laboratories (URL). Radioactive Waste Management, NEA/RWM/R(2013)2, p. 53. Co-operation and Organisation for Economic Development, Paris, France.

Parisio, F. (2016). Constitutive and numerical modelling of anisotropic quasi-brittle shales. PhD Thesis, Swiss Federal Institute of Technology in Lausanne (EFPL), Lausanne, Switzerland, p. 260.

Pearson, F. J., Arcos, D., Bath, A., Boisson, J.-Y., Fernandez, A., Gaebler, H.-E., Gaucher, E., Gautschi, A., Griffault, L., Hernan, P., \& Waber, H. N. (2003). Geochemistry of Water in the Opalinus Clay Formation at the Mont Terri Rock Laboratory (Synthesis Report). Geological Report, No. 5, p. 321. Federal Office of Topography (swisstopo), Wabern, Switzerland. http:// www.mont-terri.ch.
Peters, M., Mazurek, M., Jaeggi, D., \& Müller, H. R. (2011). WS-H Experiment: Heterogeneities in the sandy facies of Opalinus Clay on a scale of millimeters to centimetres, Mont Terri Technical Note, TN 2010-76, p. 18. Federal Office of Topography (swisstopo), Wabern, Switzerland. http://www.mont-terri. ch.

Reisdorf, A. G., Wetzel, A., Schlatter, R., \& Jordan, P. (2011). The Staffelegg formation: A new stratigraphic scheme for the Early Jurassic of northern Switzerland. Swiss Journal of Geosciences, 104, 97-146.

Schaeren, G., \& Norbert, J. (1989). Tunnels du Mont Terri et du Mont Russelin-La traversée des "roches à risques": Marnes et marnes à anhydrite. Juradurchquerungen aktuelle Tunnelprojekte im Jura Mitteilungen der Schweizerischen Gesellschaft fiir Boden- und Felsmechanik, 119, 19-24.

Schmidt, C., Braun, L., Paltzer, G., Mühlberg, M., Christ, P., \& Jacob, F. (1924). Die Bohrungen von Buix bei Pruntrut, und Allschwil bei Base. Beiträge zur Geologie der Schweiz, Geotechnische Serie (Vol. 10, p. 74). Zurich: Aschmann \& Scheller.

Schuster, K., Amann, F., Yong, S., Bossart, P., \& Connolly, P. (2017). High-resolution mini-seismic methods applied in the Mont Terri rock laboratory (Switzerland). Swiss Journal of Geosciences, 110. doi:10.1007/s00015-016-0241-4 (this issue).

SFOE. (2008). Sectorial Plan for Deep Geological Repositories, Conceptual Part. Swiss Federal Office of Energy (SFOE) Report, p. 99. Federal Office of Energy, Ittigen, Switzerland. http://www. bfe.admin.ch.

Sommaruga, A. (1999). Décollement tectonics in the Jura foreland fold and thrust belt. Marine and Petroleum Geochemistry, 16(2), 111-134.

Tripet, J. P., Brechbühler, Y. A., Haarpaintner, R. T., \& Schindler, B. (1990). Hydrogéologie des milieux à faible perméabilité: Étude des Marnes aaléniennes dans la galerie de des milieux à faible perméabilité: Étude des Marnes aaléniennes dans la galerie de reconnaissance du Mont Terri (Canton du Jura). Bulletin de la Société Neuchâteloise des Sciences Naturelles, 113, 179-189.

Vinsot, A., Appelo, C. A. J., Lundy, M., Wechner, S., CailteauFischbach, C., de Donato, P., Pironon, J., Lettry, Y., Lerouge, C., \& De Cannière, P. (2017). Natural gas extraction and artificial gas injection experiments in Opalinus Clay, Mont Terri rock laboratory (Switzerland). Swiss Journal of Geosciences, 110. doi:10.1007/s00015-016-0244-1 (this issue).

Wetzel, A., \& Allia, V. (2003). Der Opalinuston in der Nordschweiz: Lithologie und Ablagerungsgeschichte. Eclogae Geologicae Helvetiae, 96(3), 451-469.

Wieczorek, K., Gaus, I., Mayor, J. C., Schuster, K., García-Siñeriz, J-L., \& Sakaki, T. (2017). In-situ experiments on bentonitebased buffer and sealing materials at the Mont Terri rock laboratory (Switzerland). Swiss Journal of Geosciences, 110 doi: 10.1007/s00015-016-0247-y (this issue).

Yu, C., Matray, J.-M., Gonçalvès, J., Jaeggi, D., Gräsle, W. Wieczorek, K., Vogt, T., \& Sykes, E. (2017). Comparative study of methods to estimate hydraulic parameters in the hydraulically undisturbed Opalinus Clay (Switzerland). Swiss Journal of Geosciences, 110. doi:10.1007/s00015-016-0257-9 (this issue).

Ziefle, G., Matray, J-M., Maßmann, J., \& Möri, A. (2017). Coupled hydraulic-mechanical simulation of seasonally induced processes in the Mont Terri rock laboratory (Switzerland). Swiss Journal of Geasciences, 110. doi:10.1007/s00015-016-0252-1 (this issue). 